\title{
Idealized WRF model sensitivity simulations of sea breeze types and their effects on offshore windfields
}

\author{
C. J. Steele ${ }^{1}$, S. R. Dorling ${ }^{1,2}$, R. von Glasow ${ }^{1}$, and J. Bacon ${ }^{2}$ \\ ${ }^{1}$ School of Environmental Sciences, University of East Anglia, Norwich, Norfolk, NR4 7TJ, UK \\ ${ }^{2}$ Weatherquest Ltd, University of East Anglia, Norwich, Norfolk, NR4 7TJ, UK
}

Correspondence to: C. J. Steele (christopher.steele@uea.ac.uk)

Received: 26 April 2012 - Published in Atmos. Chem. Phys. Discuss.: 26 June 2012

Revised: 21 November 2012 - Accepted: 3 January 2013 - Published: 15 January 2013

\begin{abstract}
The behaviour and characteristics of the marine component of sea breeze cells have received little attention relative to their onshore counterparts. Yet there is a growing interest and dependence on the offshore wind climate from, for example, a wind energy perspective. Using idealized model experiments, we investigate the sea breeze circulation at scales which approximate to those of the southern North Sea, a region of major ongoing offshore wind farm development. We also contrast the scales and characteristics of the pure and the little known corkscrew and backdoor sea breeze types, where the type is pre-defined by the orientation of the synoptic scale flow relative to the shoreline. We find, crucially, that pure sea breezes, in contrast to corkscrew and backdoor types, can lead to substantial wind speed reductions offshore and that the addition of a second eastern coastline emphasises this effect through generation of offshore "calm zones". The offshore extent of all sea breeze types is found to be sensitive to both the influence of Coriolis acceleration and to the boundary layer scheme selected. These extents range, for example for a pure sea breeze produced in a $2 \mathrm{~m} \mathrm{~s}^{-1}$ offshore gradient wind, from $0 \mathrm{~km}$ to $21 \mathrm{~km}$ between the Mellor-Yamada-Nakanishi-Niino and the Yonsei State University schemes respectively. The corkscrew type restricts the development of a backdoor sea breeze on the opposite coast and is also capable of traversing a $100 \mathrm{~km}$ offshore domain even under high along-shore gradient wind speed $\left(>15 \mathrm{~m} \mathrm{~s}^{-1}\right.$ ) conditions. Realistic variations in sea surface skin temperature and initializing vertical thermodynamic profile do not significantly alter the resulting circulation, though the strengths of the simulated sea breezes are modulated if the effective land-sea thermal contrast is altered. We highlight how sea breeze impacts on circulation
\end{abstract}

need to be considered in order to improve the accuracy of both assessments of the offshore wind energy climate and forecasts of wind energy output.

\section{Introduction}

The sea breeze has been documented in historical texts as early as ancient Greece and to date there have been as many as 1300 articles on the subject, making the sea breeze one of the most intensely studied meso-scale meteorological phenomena. Consequently, the structure and physics of the sea breeze onshore are well known, including the features such as Kelvin-Helmholtz instabilities, sea breeze head, and associated frontal components (Simpson, 1994; Fig. 1). By far the largest contributor, accounting for approximately half of the aforementioned literature, are air quality and pollution studies (Borge et al., 2008; Lee et al., 2011; Fernández-Camacho et al., 2010). Depending on the position and height of the pollution source, the sea breeze can act to either concentrate or disperse pollutants. With a large proportion of the global population living in proximity to a coastline, and the sea breeze representing a significant feature of the seasonal coastal climate, forecasting both the physics and chemistry of these features is consequently of high importance. Furthermore, sea breezes also interact with other thermally induced flows such as with mountain valley winds, with urban heat island circulations and indeed with other sea breeze systems (e.g. Clarke et al., 1981; Bianco et al., 2006; Tsunematsu et al., 2009). They have even been associated with severe localized flooding (Golding et al., 2005). 


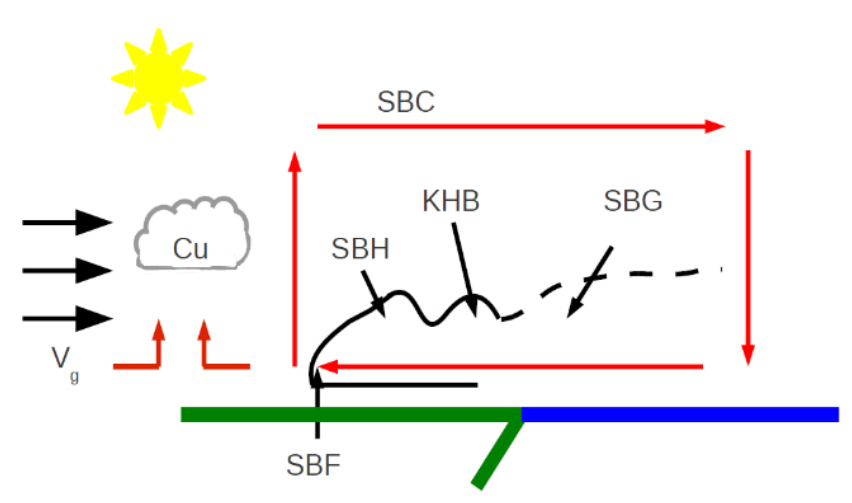

Fig. 1. Classical representation of a pure sea breeze adapted from Miller et al. (2003). The labelled features are the Sea Breeze Circulation (SBC), Sea Breeze Head (SBH), Cumulus $(\mathrm{Cu})$, Sea Breeze Gravity Current $(\mathrm{SBG})$, Gradient wind $\left(V_{\mathrm{g}}\right)$, Sea Breeze Front (SBF) and Kelvin-Helmholtz Billows (KHB).

Since a sea breeze is able to form on any coastline where the land-sea temperature gradient is sufficiently strong to overcome any synoptic pressure gradient, sea breeze study locations vary tremendously. Studies commonly appear in the literature focusing on Spain (Azorin-Molina et al., 2011a), Japan (e.g. Tsunematsu et al., 2009), Australia (e.g. Clarke, 1989), Sardinia (e.g. Furberg et al., 2002), Finland (e.g. Savijarvi and Alestalo, 1988), Greece (e.g. Papanastasiou et al., 2010) and the United States of America (e.g. Challa et al., 2009).

With the myriad of possible motivations, interactions and locations to study sea breezes, it is easy to explain the number of articles and thorough reviews can be found in Abbs and Physick (1992), in Miller et al. (2003) and in Crosman and Horel (2010) for additional information. However, notwithstanding this extensive literature on sea breeze characteristics, interactions and study locations, there is a general absence of studies focusing on the marine component despite being of great relevance to the developing offshore wind energy industry (Crosman and Horel, 2010). Also apparent is a general lack of attention given to the different sea breeze types, which are classified in accordance with the orientation of the gradient wind relative to the coastline, adding further complexity to the task of forecasting (Hoddinott, 2009; Miller et al., 2003). Both of these aspects are investigated further here.

Defined originally from nautical origins, as described by Miller et al. (2003), sea breeze types are known in the Northern Hemisphere as:

- Pure: sea breeze circulation with largest gradient wind component perpendicular to the coast and in the offshore direction (Fig. 1).

- Corkscrew: sea breeze with largest gradient wind component parallel to the coast and land surface to the left (Fig. 2).
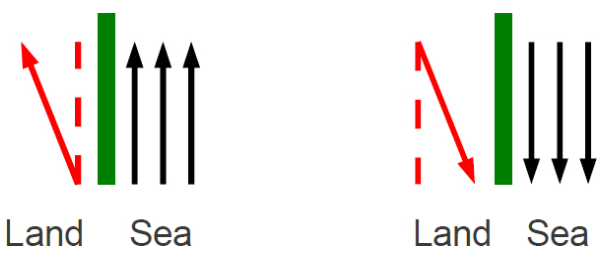

Fig. 2. Plan views of corkscrew (left) and backdoor (right) sea breeze generating scenarios depicting the effect of shore parallel gradient winds on a coastline (green). The black arrows depict the unaltered gradient wind direction. The red arrows portray frictional effects on the gradient flow at the coastline.

- Backdoor: sea breeze with largest gradient wind component parallel to the coast and land surface to the right (Fig. 2)

The pure type is the most intensely studied type of sea breeze (Crosman and Horel, 2010; Finkele, 1998; AzorinMolina and Chen, 2009). Primarily, this is due to the ease of creation of an identification method relying on the winds reversing from offshore to onshore (e.g. Azorin-Molina et al., 2011b). Diagnosing the offshore extent of a sea breeze is also simpler with the pure type, since a distance offshore can be defined where the wind speed exceeds a particular threshold (Arritt, 1989).

When considering along-shore gradient winds and the subsequent generation of corkscrew and backdoor sea breezes, the Buys-Ballot law and frictional differences must be taken into account (Fig. 2). In the corkscrew case, the Buys-Ballot law implies that low pressure is situated over the land surface. This, when combined with frictional differences between land and sea, creates a region of divergence at the coastal boundary that strengthens the sea breeze circulation. Consequently, it is the case that a corkscrew sea breeze could form with a weaker thermal contrast, relative to the pure type. Conversely the Buys-Ballot law implies that, for the backdoor sea breeze, low pressure is situated over the sea and therefore a region of convergence is created at the coast. Consequently, this implies that a stronger thermal contrast is needed between the land and sea to generate this type of sea breeze.

Crosman and Horel (2010) note that there are both a lack of studies focusing on the onshore sea breeze cell component in the offshore environment and a deficiency looking at sea breeze sensitivity to the extent of the water body. Indeed, in a review of over $50 \mathrm{yr}$ of sea breeze modelling studies they highlight only two influential papers focusing entirely on the offshore component. In the first study by Arritt (1989), 2and 3-dimensional model simulations were performed to determine the environmental controls on the offshore extent of sea breezes. Arritt (1989) defined the offshore extent to be the region where onshore wind speeds were greater than $1 \mathrm{~m} \mathrm{~s}^{-1}$. Latitude and synoptic forcing were found to have the most significant effect; both higher latitudes and offshore gradient 
flows greatly reduced the offshore extent. For example, increasing the latitude from $0^{\circ} \mathrm{N}$ to $40^{\circ} \mathrm{N}$ reduced the offshore extent of the sea breeze from $160 \mathrm{~km}$ to $113 \mathrm{~km}$. It was determined that if the Sea Surface Temperature (SST) was sufficiently warm to produce a convective boundary layer, then the sea breeze was weakened. However, if the water was already sufficiently cold to produce a stable surface layer, any further cooling did not have an additional effect. Decreasing the SST from $293 \mathrm{~K}$ to $283 \mathrm{~K}$, decreased the sea breeze offshore extent by $25 \mathrm{~km}$, however, a further reduction in SST to $273 \mathrm{~K}$ only caused a further $6 \mathrm{~km}$ reduction in offshore horizontal extension.

More recently, in the second study, Finkele (1998) used a 3-dimensional hydrostatic model to ascertain offshore propagation speeds, with the help of airborne measurements. Principally, in contrast to Arritt (1989), it was found that the offshore extent was similar for both light $\left(2.5 \mathrm{~m} \mathrm{~s}^{-1}\right)$ and moderate $\left(5 \mathrm{~m} \mathrm{~s}^{-1}\right)$ offshore gradient wind conditions. The propagation speeds for both onshore and offshore development were non-uniform at these wind speeds. Finkele (1998) also suggested that the onshore extent was more sensitive to gradient wind speed than the offshore, though it was added that during periods when wind speeds were greater than $7.5 \mathrm{~m} \mathrm{~s}^{-1}$ the sea breeze had become entirely detached and so it was no longer possible to confirm. Both studies report, however, that the offshore extent can be several times that of the onshore, and can reach distances ranging from $75-150 \mathrm{~km}$. Potentially, this could be restricted if there were an additional coastline on the opposite side of the sea, similarly generating sea breeze circulations.

Unfortunately, the effect of a second coastline is an important detail that is also under-studied; Savijarvi and Alestalo (1988) addressed this point but, even so, their primary focus remained on the inland component. Their approach was to use a 2-dimensional mesoscale model to simulate sea breezes across a channel $80 \mathrm{~km}$ wide with SST, land surface temperature and roughness length variations representative of the Gulf of Finland. Both wind speed and direction were varied to examine the behaviour of the sea breeze in this situation. In particular, Savijarvi and Alestalo (1988) note that the sea breeze was insensitive to the strength of along-shore gradient winds, however offshore winds generated a low level jet along the coast and suppressed sea breeze inland penetration.

More recently, Crosman and Horel (2012) performed idealized large eddy simulations of both sea and lake breezes. Sensitivity tests were performed on lakes of varying size, up to $100 \mathrm{~km}$. However the focus of the study was once again in the onshore environment. The effect of varying the width of the water source produced sea/lake breezes which did not conform to sea breeze scaling parameters, suggesting that lake breezes should be treated differently. For a $100 \mathrm{~km}$ lake, however, the lake breeze characteristics matched those of a sea breeze in terms of sensitivity to heat flux and vertical stability.
The behaviour of corkscrew and backdoor sea breezes is also largely under-studied. References to the types, as described by Miller et al. (2003), are usually implicit. For example, Gahmberg et al. (2010) studied the effects of incrementally varying wind direction and found that the sea breeze is stronger for geostrophic flows $45-90^{\circ}$ left of perpendicular from the coastline (approaching from the sea), indicative of a corkscrew sea breeze.

There is now a pressing need to progress our understanding of the scale and climatology of the marine component of the sea breeze cell to support the rapidly expanding offshore wind energy industry. Around the coast of Britain, there are currently 17 offshore wind farms, with a further 21 either under construction or in planning (Fig. 3). Such is the scale of the industry that, by 2020, it is planned that offshore wind power will account for $17 \%$ of the total electrical power output of the UK (RenewableUK, 2012; Cleantech, 2010). A large proportion of these wind farms are situated in the relatively shallow southern North Sea between the UK and mainland Europe. The horizontal extent of the North Sea, for example between Gunfleet Sands (south east England) and Thornton Bank (western Netherlands), is approximately $100 \mathrm{~km}$ (Fig. 3).

With such a high percentage of UK electricity production predicted to be generated from offshore wind farms in the future, accurate forecasting of power production from offshore wind turbines is essential for all stakeholders, both from a resource and a financial contract perspective. The cubic relationship between wind speed and power production which exists for wind turbines is especially important here.

Furthermore, the climatology of sea breezes forming off the east coast of England is not well known. This is especially the case for corkscrew and backdoor sea breeze types. Simpson et al. (1977) observed 76 pure sea breeze events on the south coast of England during the period 1962-1973, and to date, this remains the most extensive climatology of sea breeze events for the UK. The frequency of sea breeze occurrence each year is also likely to fluctuate due to the high degree of variability in the UK wind climate (Earl et al., 2012). It is therefore vital to address the frequency of sea breeze occurence, the effect of a second coastline on the offshore wind regime during sea breeze episodes and to assess the potential impact of individual events on the wind energy industry.

With a very limited amount of offshore measurement data available, the few studies that have examined sea breeze marine components have often been restricted to numerical simulations. Here, we perform numerical simulations of idealized sea breezes using the Weather Research and Forecasting (WRF) model, testing the response to SST variations, Coriolis forcing, initializing thermodynamic profiles and the strength and direction of the gradient wind. Three different boundary layer physics schemes are also tested in order to assess the consistency of results in terms of timing, extent, duration and strength of the sea breeze. 


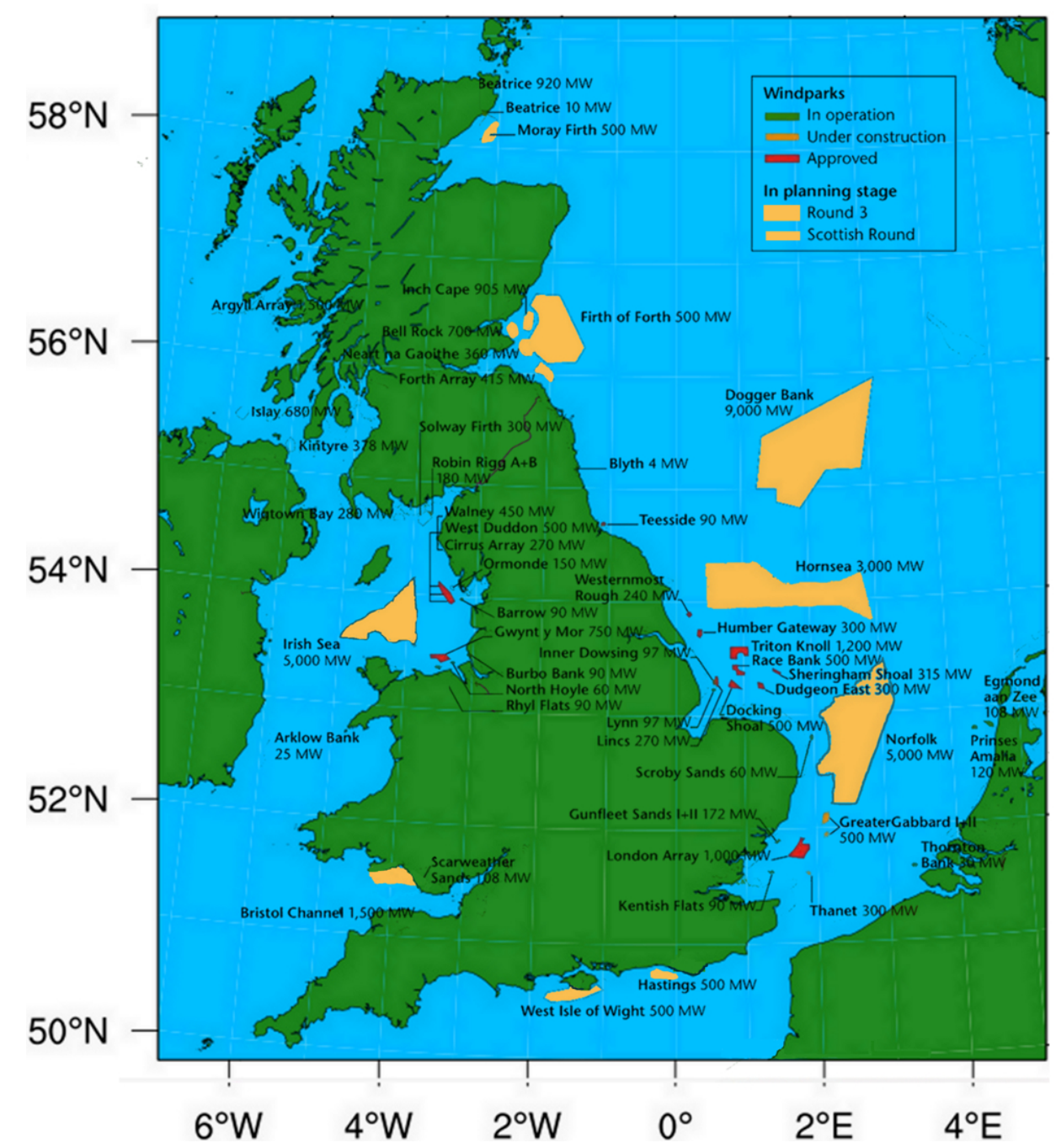

Fig. 3. The locations of constructed or planned offshore wind farms in the UK (Map adapted from Cleantech, 2010).

\section{Methods}

For each simulation, the idealized version of the Weather Research and Forecasting (WRF) model was used, that is, using the full physics equations but with a 2-dimensional model domain (Skamarock and Klemp, 2008). It has been noted by Crosman and Horel (2010) that idealized studies to date overwhelmingly use idealized vertical profiles as initial conditions and so subsequently there is a need to move towards using observations. Here, unless stated otherwise, we used a specific sounding from Herstmonceux radiosonde station in south east England (50.9 $9^{\circ}, 0.317^{\circ}$ E; Fig. 4). Simpson (1994) noted that the most common period for observing sea breezes in the UK is during June, when the land-sea thermal contrast is normally at a maximum. For this reason the sounding was chosen from 4 June 2006 during a period when sea breeze favouring anticyclonic conditions also dominated the weather of the UK. More information on this period of weather is available in the Supplement (Fig. S1).

\subsection{Single coast exploratory experiments}

Initially, several single coast simulations were conducted (Table 1) in order to act as a comparison for later dual-coast results. This was also deemed necessary since there has been disagreement in the literature about the sensitivity of the sea breeze offshore extent to gradient flow (Crosman and Horel, 2010).

For each test, the model was initialized at midnight and simulations were run for $24 \mathrm{~h}$, with a time step of $10 \mathrm{~s}$ and with output recorded every $15 \mathrm{~min}$. The simulations were restricted to $24 \mathrm{~h}$ as the definition of sea breeze type is strongly dependant on the preceding wind direction. When the simulations were extended to $48 \mathrm{~h}$, the type of sea breeze forming on the second day is a function of both the previous day's sea breeze type and the initial gradient wind forcing, as shown in the Supplement (Figs. S2-S3). Consequently, the sea breeze simulated on the second day is not necessarily of the same 


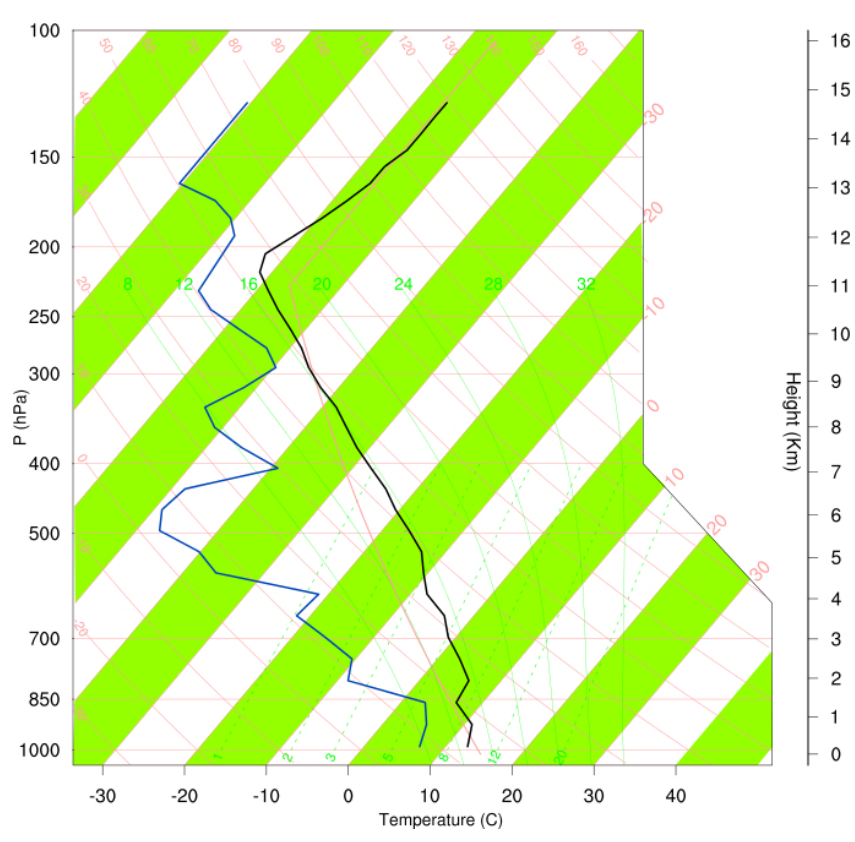

Fig. 4. The initialization vertical dry bulb (black) and dewpoint temperature (blue) skew-T profiles at the model coastline originally observed at Herstmonceux station at 00:00 UTC on 4 June 2006.

type as the original gradient wind forcing would dictate. The land use category was selected as dryland, cropland and pasture to best represent eastern England. The model domain was divided so that 100 grid points occupied land and 100 represented sea. The model horizontal resolution was $3 \mathrm{~km}$ and 35 vertical layers were distributed so that 8 layers were in the lowest $1 \mathrm{~km}$ and the remainder distributed to a height of $15 \mathrm{~km}$. The first five $\eta$ levels in the model were 0.999 , 0.997, 0.994, 0.987, 972 and 0.959, equivalent to 4, 10, 16, $40,87,170 \mathrm{~m}$ heights, on average, respectively. Model scalar variables are located on the $\eta$ levels and vector quantities reside on half levels. Vector quantities are interpolated to the scalar, or mass, points using adjacent half levels.

Coriolis acceleration was enabled for a latitude of $52^{\circ}$ for these experiments to best represent the southern North Sea. The initial land and sea skin temperatures were $280 \mathrm{~K}$ and $287 \mathrm{~K}$, respectively. Model simulations consisted of varying the along-shore and offshore gradient winds from 2 to $10 \mathrm{~m} \mathrm{~s}^{-1}$ in steps of $2 \mathrm{~m} \mathrm{~s}^{-1}$ so as to generate the different types of sea breeze. In all simulations, the u-wind component is described as positive in the offshore direction and orientated perpendicular to the coastline. The v-wind component is orientated shore parallel and positive with the land to the left. The offshore extent for all simulations was defined using the method of Arritt (1989), that is where the strength of the onshore flow breaches $1 \mathrm{~m} \mathrm{~s}^{-1}$, anything smaller than this threshold is not considered to be part of the sea breeze. A single simulation was also run without gradient winds so that a baseline could be established for comparison with the other sea breeze types. This is referred to hereafter as the base-
Table 1. WRF model and physics specifications used for the single coast baseline experiments.

\begin{tabular}{ll}
\hline WRF Setting and physics options & Value \\
\hline Horizontal resolution $(\mathrm{km})$ & 3 \\
Long wave physics & RRTM \\
Short wave physics & Monin-Obukhov similarity \\
Model top (hPa) & 50 \\
Ground physics & Noah land surface \\
PBL scheme & YSU \\
Vertical levels & 35 \\
Cumulus scheme & None \\
Microphysics & WSM-3-class \\
Coriolis $\left(\mathrm{s}^{-1}\right)$ & $1.15 \times 10^{-4}$ \\
\hline
\end{tabular}

line experiment for which the model physics and settings are described in Table 1. Additional simulations were also undertaken to test the sensitivity to two alternative initializing thermodynamic profiles (Fig. 5).

\subsection{Dual coast experiments}

A second coastline was then added so that a central sea channel occupied the central $99 \mathrm{~km}$ of the model domain (Fig. 6). Once again, the land use category was selected as dryland, cropland and pasture to best represent the UK and mainland Europe. Simulations were run to test the effect of varying gradient wind strengths, Sea Surface Temperature (SST) and Coriolis on three different Planetary Boundary (PBL) schemes: the Yonsei State University (YSU), the MellorYamada-Janjic (MYJ) and the Mellor-Yamada-NakanishiNiino (MYNN) schemes (Table 2). SST variations matched those typically experienced in the southern North Sea during June and were between $280-290 \mathrm{~K}$ in steps of $1 \mathrm{~K}$. Simulations were also carried out with and without Coriolis acceleration for a latitude of $52^{\circ}$, since the effect of Coriolis variations with latitude on the sea breeze is rarely studied (Crosman and Horel, 2010).

The YSU scheme is a non-local turbulence closure scheme with explicit treatment of the entrainment process (Hong et al., 2006). The scheme includes a parabolic K-mixing profile for the convective boundary layer and the use of the bulk Richardson number to determine PBL height. The YSU PBL scheme has been shown to give a good representation of a sea breeze in previous simulations (Challa et al., 2009). However, in the context of offshore wind energy forecasting, it was shown by Krogsaeter et al. (2011) that the YSU scheme consistently produces a profile which is excessively neutral offshore, though this was more notable for higher wind speeds. Their study is particularly relevant as Krogsaeter et al. (2011) make use of measurements made on the FINO 1 platform, located in the southern North Sea, to verify their PBL sensitivity experiments. 


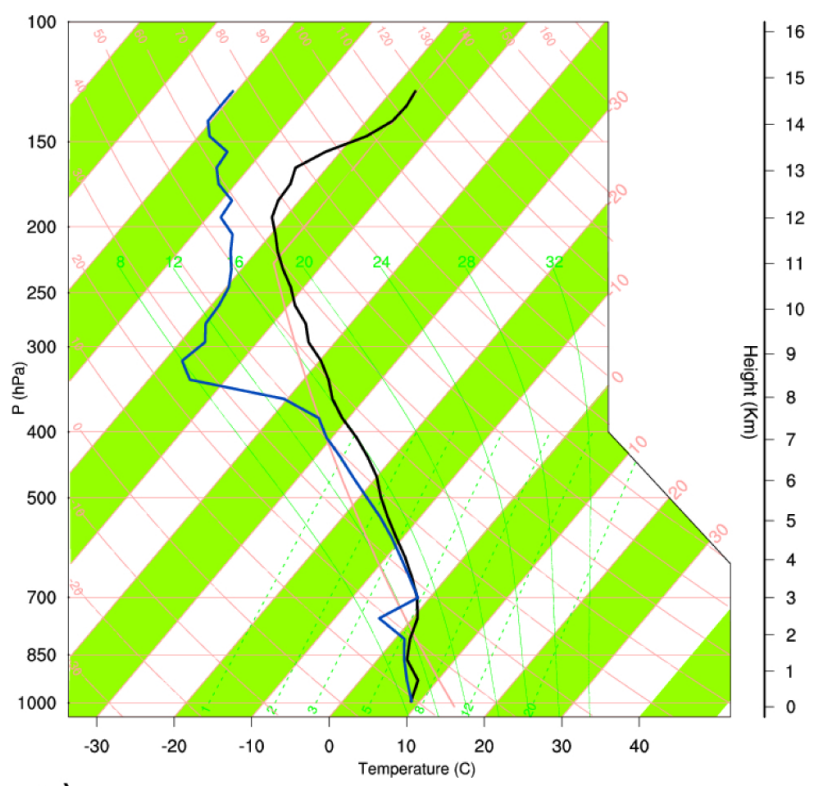

a)

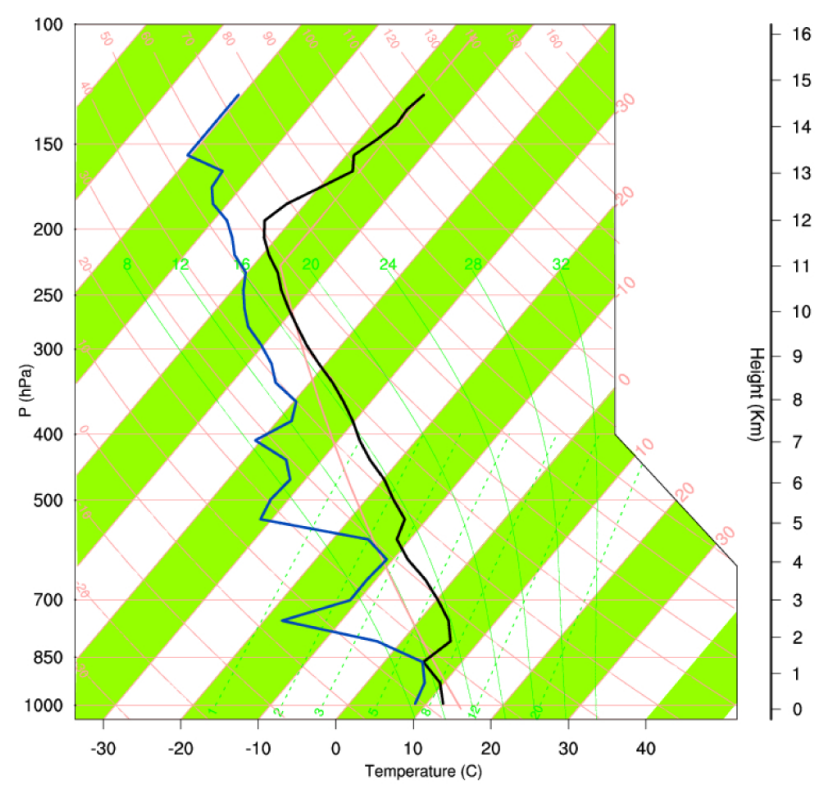

b)

Fig. 5. Skew-T profiles from Herstmonceux station at (a) 00:00 UTC, 2 June 2006 and (b) 00:00 UTC, 3 June 2006.

The MYJ turbulence closure scheme is a level 2.5, 1.5order Turbulent Kinetic Energy (TKE) scheme that uses local vertical mixing in both the boundary layer and the free atmosphere (Mellor and Yamada, 1982). To diagnose PBL height, the MYJ scheme uses a critical TKE value of $0.001 \mathrm{~m}^{2} \mathrm{~s}^{-2}$, whereby values below this are classed as the free atmosphere. Similar to the MYJ scheme, the MYNN is also a level 2.5 TKE scheme which uses the same basic TKE equations to complete turbulence closure. The difference between the MYJ and the MYNN schemes lies in the definition of

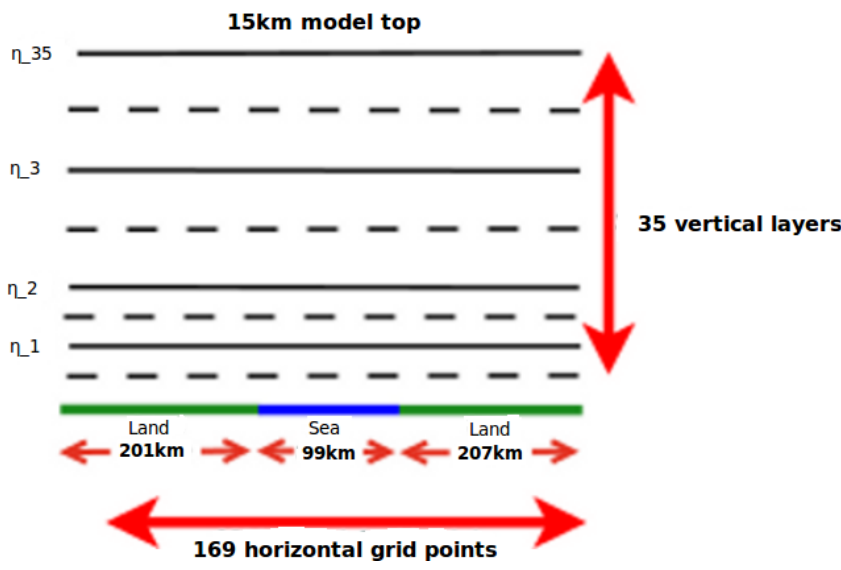

Fig. 6. Model configuration for dual-coast experiments. Dashed lines indicate half levels on the Arakawa C-staggered grid used in the WRF model.

Table 2. Sensitivity tests for the dual-coast experiments. The u-wind is orientated shore perpendicular and positive in the offshore direction and the v-wind is shore parallel and positive with land to the left.

\begin{tabular}{ll}
\hline Parameter & Sensitivity test \\
\hline $\mathrm{u}$-wind $\left(\mathrm{m} \mathrm{s}^{-1}\right)$ & 0 to 20, steps of 1 \\
$\mathrm{v}$-wind $\left(\mathrm{m} \mathrm{s}^{-1}\right)$ & -20 to 20, steps of 1 \\
SST $(\mathrm{K})$ & 280 to 290, steps of 1 \\
PBL Schemes & YSU, MYNN (level 2.5), MYJ \\
Coriolis $\left(\mathrm{s}^{-1}\right)$ & $0,1.15 \times 10^{-4}$ \\
\hline
\end{tabular}

the master length scale, which is important for the calculation of TKE. The MYNN scheme is much more complex than the MYJ, due to the explicit treatment of stability. Also, the MYNN scheme was verified using large-eddy simulations as this, unlike observations which were used for the MYJ scheme, prevents possible contamination by nonstationary mesoscale phenomena (Esau and Byrkjedal, 2007). Both TKE schemes performed better than the YSU scheme in the study by Krogsaeter et al. (2011), though notably the MYJ scheme has a tendency to produce overly shallow boundary layers (Sun and Ogura, 1980).

Finally, another baseline simulation is run without gradient winds for the dual-coast cases.

\section{Results}

\subsection{Single coast experiments}

\subsubsection{Baseline case (no gradient wind)}

$150 \mathrm{~km}$ onshore, the baseline case produces a boundary layer which reaches a maximum height of approximately $1550 \mathrm{~m}$ over the land surface (Fig. 7). This height is reached at 


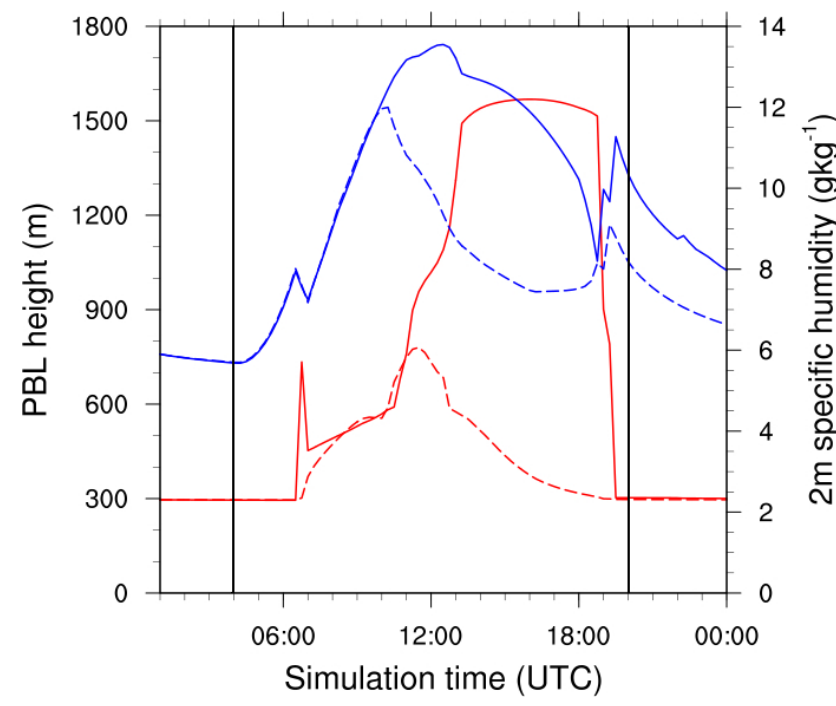

Fig. 7. Daytime evolution of PBL height (red) and $2 \mathrm{~m}$ specific humidity (blue) for the baseline single coast simulation using the YSU PBL scheme and an SST of $287 \mathrm{~K}$. Solid lines indicate values $150 \mathrm{~km}$ onshore and dashed lines are at the coastline. Sunrise and sunset times are represented by the solid vertical black lines

approximately 14:00 UTC and lasts until 18:45 UTC where upon the boundary layer collapses. Similarly, the background specific humidity steadily rises to $13.5 \mathrm{~g} \mathrm{~kg}^{-1}$, reaching its peak approximately $15 \mathrm{~min}$ before the maximum height in the PBL (Fig. 7).

The maximum $2 \mathrm{~m}$ land temperature is approximately $303 \mathrm{~K}$, giving a maximum land-sea temperature difference $270 \mathrm{~km}$ inland of $16 \mathrm{~K}$ (Fig. S4). The diurnal cycle, without the influence of the sea breeze, is affected by the development of cloud at $850 \mathrm{hPa}$ which causes the local minimum at 13:00 UTC. This is specific to the initial sounding. Regardless of the effects of the initializing vertical thermodynamic profile, the amplitude of the diurnal cycle $270 \mathrm{~km}$ inland from sunrise at 04:00 UTC to sunset at 20:00 UTC is $23 \mathrm{~K}$.

From approximately 02:00-09:00 UTC, a light shallow circulation near the surface is established over the coastline, indicative of a land breeze (Fig. 8). This breaks down and a very weak sea breeze with return flow emerges simultaneously, but it is not until after 12:00 UTC, that the sea breeze strength breaches the $1 \mathrm{~m} \mathrm{~s}^{-1}$ threshold and continues to intensify to $2.5 \mathrm{~m} \mathrm{~s}^{-1}$ by 18:00 UTC (Fig. 8 ).

The effect of the onset of the sea breeze on the PBL is to prevent entrainment and the consequent development of the convective boundary layer. Since the determination of the PBL height is, in this case, based on the bulk Richardson number, an increase in the strength of shear turbulence brought about by the formation of the sea breeze, suppresses the buoyancy instability over the land surface and therefore stabilizes the PBL. The arrival of the sea breeze also causes the specific humidity to drop (Fig. 7) in agreement with observations by Finkele (1998).

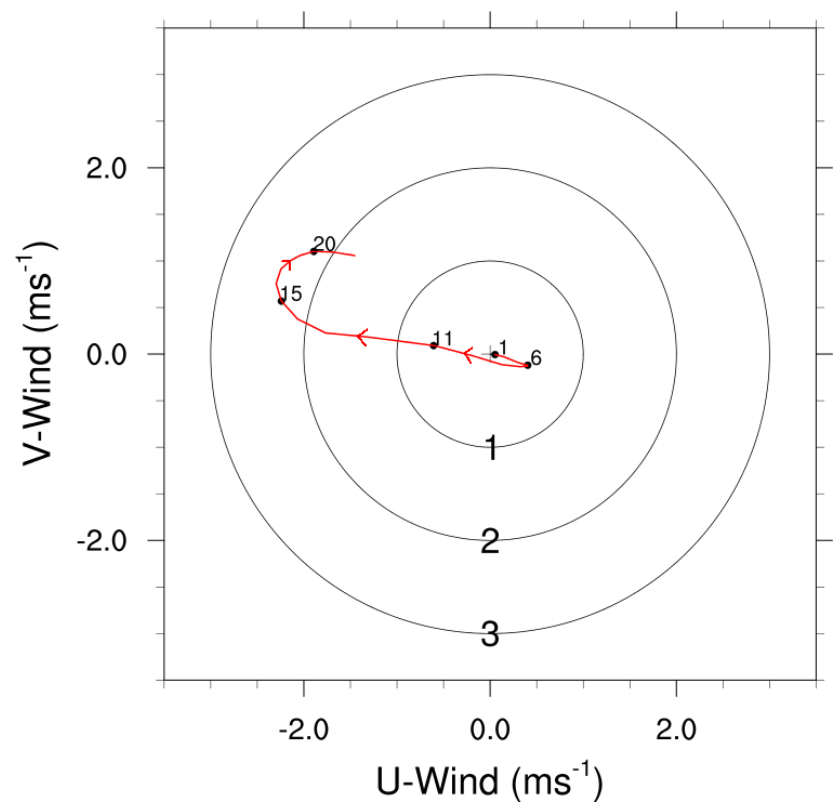

Fig. 8. Hodograph of the single coast baseline simulation at the coastline using the YSU PBL scheme and an SST of $287 \mathrm{~K}$. Numbers labelled on the curve represent the simulation hour in UTC and concentric circles portray the magnitude of the $10 \mathrm{~m}$ vector wind. The negative $\mathrm{u}$-wind component represents onshore flow and the negative v-wind component represents shore parallel flow with the land mass to the right.

The overall depth of the sea breeze landward component is approximately $700 \mathrm{~m}$, with a seaward return flow depth which is approximately twice the magnitude (Fig. 9). The depths found are consistent with observations presented by Simpson (1994) of sea breezes along the south coast of England, and with the numerical experiments by Finkele (1998) and Arritt (1989). Ahead of the sea breeze onshore, a region of calm $\left(<1 \mathrm{~m} \mathrm{~s}^{-1}\right)$ onshore flow of approximately the same length, but double the thickness of the sea breeze onshore flow, persists for the duration of the simulation. This is indicative of continental air moving inland as the sea breeze advances (Miller et al., 2003). The continental air is deeper than the incoming sea breeze due to surface heating ahead of the sea breeze front (Crosman and Horel, 2012; Fig. S5). A vertically propagating wave develops as shown in Fig. 9, and reaches a maximum height of $12 \mathrm{~km}$ by the end of the simulation. To our knowledge, there have been no observations of the vertically propagating wave in a sea breeze circulation, but they are frequently seen in simulations of mountain winds and other sea breeze numerical studies (e.g. Klemp and Lilly, 1978; Qian et al., 2009). Further study into this is beyond the scope of this paper since our primary focus remains on the offshore environment. Further information regarding the sea breeze characteristics in the onshore environment is available in the Supplement. 


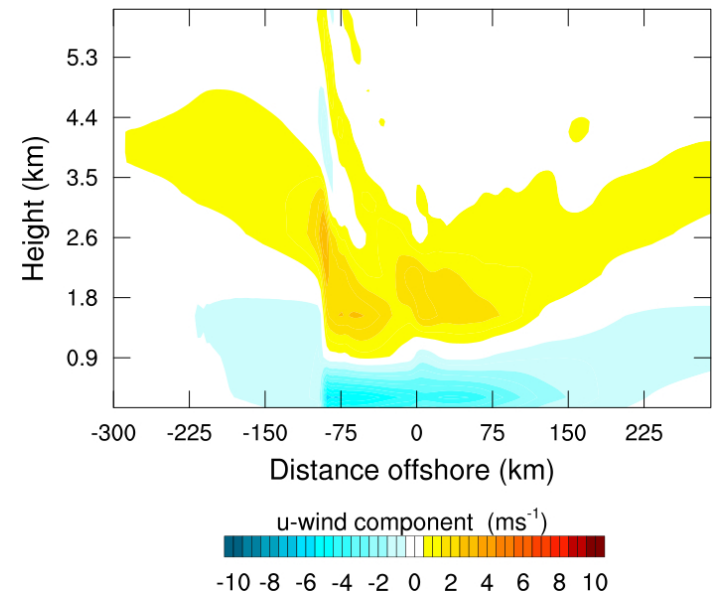

Fig. 9. The $\mathrm{u}$-wind component $\left(\mathrm{m} \mathrm{s}^{-1}\right)$ of a mature sea breeze at 19:00 UTC for the baseline single coast case using the YSU PBL scheme and a SST of $287 \mathrm{~K}$. Negative values indicate onshore flow.

Applying the wind speed threshold criteria defined by Arritt (1989) over the modelled sea, the sea breeze is more than capable of reaching over $250 \mathrm{~km}$ offshore. However, the scale of offshore advancement is sensitive to the speed threshold set for defining a sea breeze. For example, increasing the threshold to $1.5 \mathrm{~m} \mathrm{~s}^{-1}$ results in a reduction of approximately a third in offshore advancement. Even at this threshold of $1.5 \mathrm{~m} \mathrm{~s}^{-1}$, the sea breeze still reaches $170 \mathrm{~km}$ offshore, well above the typical length scale of the southern North Sea (Fig. S6).

\subsubsection{Pure sea breeze}

For a pure type sea breeze with an offshore gradient wind of $2 \mathrm{~m} \mathrm{~s}^{-1}$ the return flow component first establishes over the coast at 11:00 UTC, two hours before the development of the low level onshore flow (Table 3), unlike the baseline case where they are coincident. There is, however evidence of a weakening of the gradient wind at low levels, due to the establishment of a temperature gradient. The offshore extent becomes approximately equal to the baseline case for this gradient wind speed, extending to a maximum of $270 \mathrm{~km}$ offshore (Fig. 10). East of the seaward end of the sea breeze a calm zone $\left(10 \mathrm{~m}\right.$ wind speed $\left.<1 \mathrm{~m} \mathrm{~s}^{-1}\right)$ rapidly expands, so that by 19:00 UTC, the influence of the pure sea breeze extends across the entire offshore domain. The presence of a calm zone offshore has been observed in the southern North Sea by Lapworth (2005) though only extending between 20 $40 \mathrm{~km}$ during offshore gradient wind flow.

Increasing the gradient offshore wind speed results in a delay in the establishment of the full sea breeze circulation. For example, increasing the offshore gradient wind from the baseline to $4 \mathrm{~m} \mathrm{~s}^{-1}$ results in a delay of $2 \mathrm{~h}$ (Fig. 10). The onshore component also weakens with increasing gradient wind speed to the extent that once the gradient speed becomes

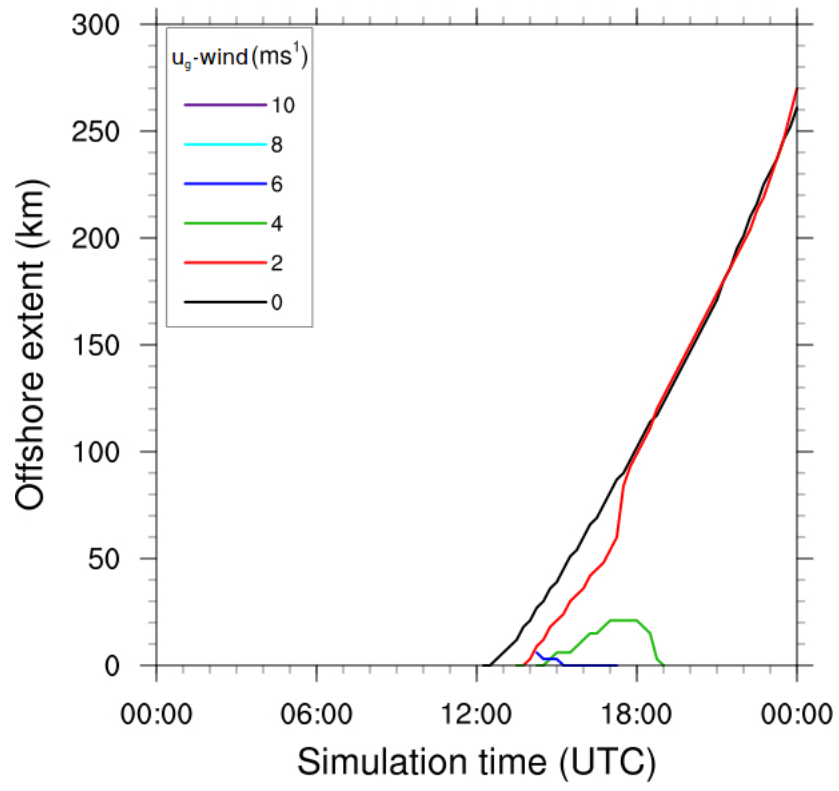

Fig. 10. Sensitivity of onset time and offshore extent of a single coast pure sea breeze to the strength of the offshore gradient flow $\left(U_{\mathrm{g}}\right)$. In all tests, the YSU PBL scheme was used along with a SST of $287 \mathrm{~K}$.

equal to $8 \mathrm{~m} \mathrm{~s}^{-1}$, the onshore component does not breach the $1 \mathrm{~m} \mathrm{~s}^{-1}$ threshold used by Arritt (1989) and a sea breeze is not formed (compare Figs. 10 and 11; Figs. S7 and S8). However, weak onshore flow below the $1 \mathrm{~m} \mathrm{~s}^{-1}$ threshold is simulated at $8 \mathrm{~m} \mathrm{~s}^{-1}$ offshore gradient wind speed which does reach the coastline at 17:00 UTC. The onshore flow then weakens and does not penetrate inland (Fig. S8).

The PBL height development is not substantially different from the baseline case with increasing wind speed, although the delay with the formation of the sea breeze results in the PBL at the coast becoming deeper before the onset. Increasing the gradient wind speed results in the formation of a front, denoted by a sharp rise in specific humidity at the onset of the sea breeze which is not present in the baseline case (Fig. S9). This peak becomes more pronounced with increasing gradient wind speed until it reaches $8 \mathrm{~m} \mathrm{~s}^{-1}$ when the onshore $10 \mathrm{~m}$ wind speed is of insufficient strength to form a sea breeze.

Offshore, the horizontal extent of the sea breeze is sensitive to the strength of the gradient wind above $2 \mathrm{~m} \mathrm{~s}^{-1}$ to the degree that raising the gradient wind strength to $4 \mathrm{~m} \mathrm{~s}^{-1}$ reduces the maximum offshore extent to $21 \mathrm{~km}$ (Fig. 10). Calm zones $\left(10 \mathrm{~m}\right.$ wind speed $<1 \mathrm{~m} \mathrm{~s}^{-1}$ ), however, persist in all experiments, reaching a maximum length of $21 \mathrm{~km}$ for an offshore gradient wind speed of $10 \mathrm{~m} \mathrm{~s}^{-1}$ (Fig. S10).

In context, a typical $100 \mathrm{~m}$ offshore wind turbine has a hub height cut-in speed of $4 \mathrm{~m} \mathrm{~s}^{-1}$, whereby at wind speeds below this threshold the turbine does not operate (Sinden, 2005). Therefore it is entirely possible for a pure sea breeze, incorporating adjustment for wind speed to hub height, to have 
Table 3. Summary characteristics of different sea breeze type characteristics for single coast experiments using gradient wind speeds of $2 \mathrm{~m} \mathrm{~s}^{-1}$ and $6 \mathrm{~m} \mathrm{~s}^{-1}$ orientated offshore (pure), along shore with land to the left (corkscrew) and along shore with land to the right (backdoor). All simulations are based on the YSU PBL scheme and a SST of $287 \mathrm{~K}$.

\begin{tabular}{|c|c|c|c|c|c|c|}
\hline \multirow{2}{*}{$\begin{array}{l}\text { Parameter } \\
\text { Gradient wind speed }\left(\mathrm{m} \mathrm{s}^{-1}\right)\end{array}$} & \multicolumn{2}{|c|}{ Pure } & \multicolumn{2}{|c|}{ Corkscrew } & \multicolumn{2}{|c|}{ Backdoor } \\
\hline & 2 & 6 & 2 & 6 & 2 & 6 \\
\hline Onset (UTC) onshore flow & 13:00 & $14: 15$ & $11: 30$ & $11: 00$ & $12: 00$ & $11: 00$ \\
\hline Onshore thickness (m) & 700 & 450 & 750 & 650 & 600 & 600 \\
\hline Max wind speed $\left(\mathrm{m} \mathrm{s}^{-1}\right)$ & 3.75 & 1.13 & 4.47 & 3.76 & 4.25 & 3.88 \\
\hline Offshore advancement $\left(\mathrm{m} \mathrm{s}^{-1}\right)$ & 5.55 & - & 6.48 & 8.33 & 4.63 & 3.47 \\
\hline Onshore advancement $\left(\mathrm{m} \mathrm{s}^{-1}\right)$ & 2.89 & 1.39 & 4.11 & 4.86 & 4.36 & 3.57 \\
\hline Onshore extent $(\mathrm{km})$ & 132 & 21 & 111 & 162 & 111 & 90 \\
\hline Offshore extent $(\mathrm{km})$ & 270 & 12 & 300 & 300 & 171 & 102 \\
\hline
\end{tabular}

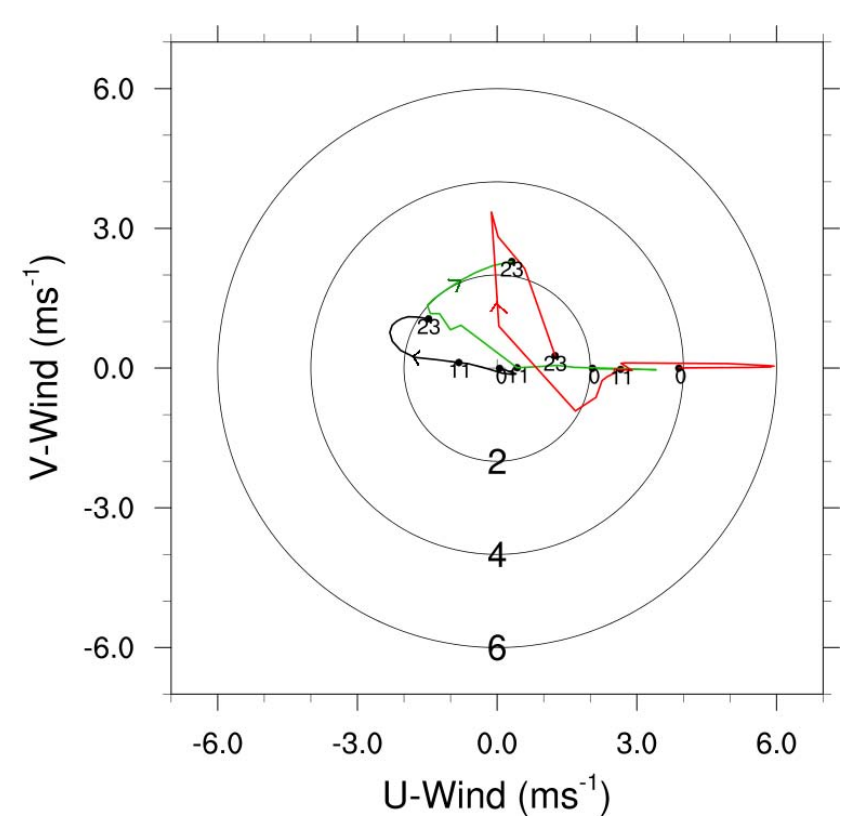

Fig. 11. Coastal $10 \mathrm{~m}$ hodograph for the baseline (black), $4 \mathrm{~m} \mathrm{~s}^{-1}$ (green) and $8 \mathrm{~m} \mathrm{~s}^{-1}$ (red) offshore gradient winds. Numbers indicate the simulation hour in UTC and concentric circles indicate the magnitude of the $10 \mathrm{~m}$ wind speed vector. The $\mathrm{u}$-wind component is positive in the offshore direction and the v-wind is positive in the shore-parallel direction with the land mass to the left. In each simulation, the PBL scheme was YSU and the SST was set to $287 \mathrm{~K}$. A single coastline was also used in all experiments.

a negative influence on wind power production. Once above this threshold, the power produced is proportional to the cube of the wind speed, so at higher gradient wind speeds the sea breeze, acting in the opposite direction, can significantly reduce power output. In cases where the land-sea thermal contrast is of insufficient strength to produce a sea breeze, or where the offshore gradient wind is too strong, there is still a significant reduction in wind speed offshore which, for a period, is below the turbine cut-in speed (Fig. 12).

\subsubsection{Corkscrew and backdoor sea breezes}

As with the pure case, the formation of a corkscrew sea breeze in $2 \mathrm{~m} \mathrm{~s}^{-1}$ shore-parallel winds involves the establishment of the return flow circulation before the onset of the low-level onshore flow. This develops at 09:00 UTC, rather than at 10:00 UTC, as with the pure case, supporting the theory that a corkscrew type sea breeze requires a weaker thermal contrast to initialize. The earlier onset time prevented the PBL height at the coast from reaching a height above $750 \mathrm{~m}$ before the arrival of the sea breeze (Fig. 13). Consequently the PBL height drop on arrival was not as sharp as with the equivalent pure case and by 16:00 UTC it had lowered to $300 \mathrm{~m}$, the height of the PBL over the sea. This pattern was replicated for specific humidity (Fig. 13).

Increasing the strength of the shore-parallel gradient flow results in both an increase in the onshore horizontal extent and an earlier onset time, unlike the pure sea breeze which does not establish for offshore gradient wind speeds over $6 \mathrm{~m} \mathrm{~s}^{-1}$ (Figs. 10, 14 and S11). Also unlike the pure sea breeze, all gradient wind strengths produce a corkscrew sea breeze which has sufficient offshore extent to cross the entire offshore domain (Fig. 14). The increase in shore-parallel gradient wind speed increases the degree of divergence from friction at the surface, consequently allowing the corkscrew sea breeze to expand more rapidly than the pure type sea breeze.

The vertical thickness of the corkscrew sea breeze is approximately $750 \mathrm{~m}$ (Fig. 15) and this does not deviate substantially for increasing along-shore gradient flow. However, the depth of the return flow appears to increase substantially with increasing along-shore gradient wind speed, though the true degree is masked by rotation of the gradient winds by Coriolis acceleration.

The backdoor sea breeze, generated by shore parallel flow with land to the right, is less sensitive to increasing gradient wind speed than the pure type sea breeze and, like the corkscrew sea breeze, establishes at a similar time (Table 3 ). However, the circulation is weaker, advancing only $111 \mathrm{~km}$ 

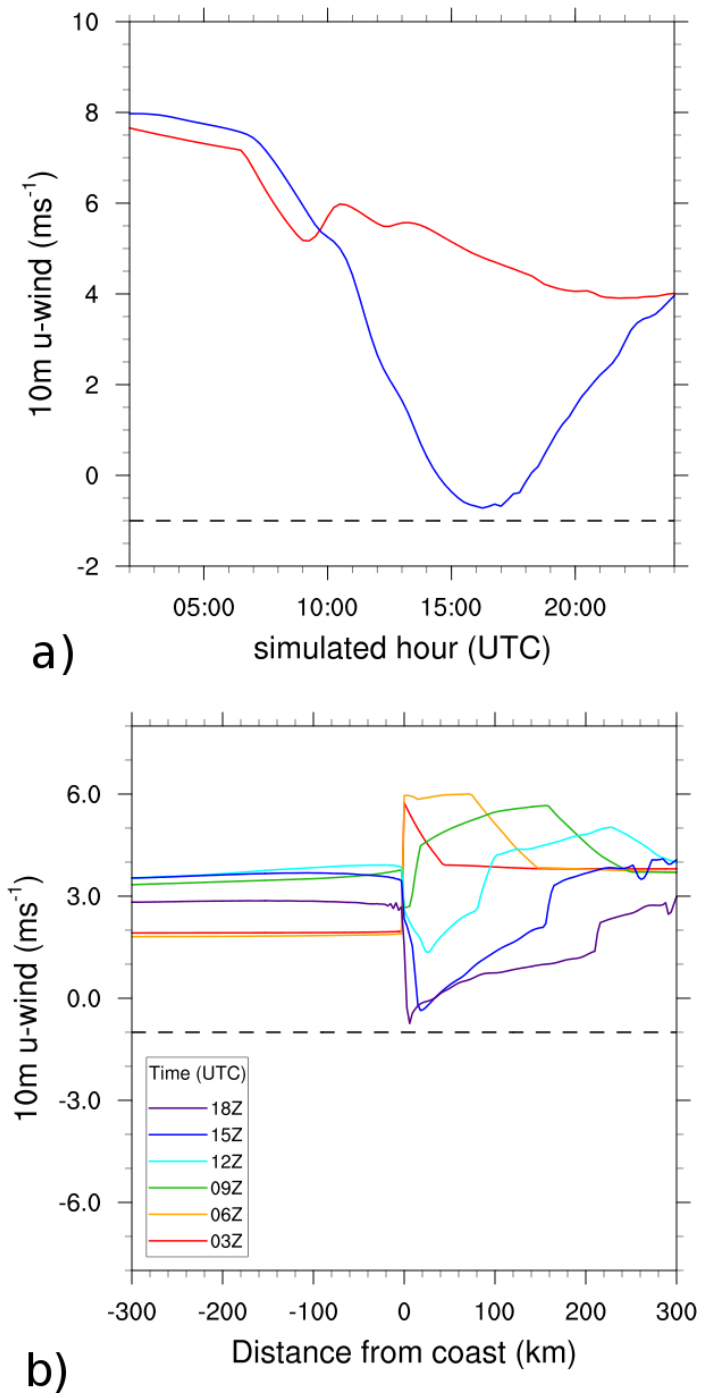

Fig. 12. (a) $10 \mathrm{~m} u$-wind speed for locations on the coastline (red) and $30 \mathrm{~km}$ offshore (blue) for a single coast pure sea breeze simulated with $8 \mathrm{~m} \mathrm{~s}^{-1}$ offshore gradient wind. (b) $10 \mathrm{~m} \mathrm{u}$-wind speed across the model domain at 03:00 (red), 06:00 (orange), 09:00 (green), 12:00 (cyan), 15:00 (blue) and 18:00 (purple) UTC. The dashed line represents the $1 \mathrm{~m} \mathrm{~s}^{-1}$ offshore wind speed threshold required for diagnosing a sea breeze. In all simulations, the YSU PBL scheme was used in conjunction with a SST of $287 \mathrm{~K}$.

at an average offshore rate of $4.63 \mathrm{~m} \mathrm{~s}^{-1}$ for a shore parallel gradient wind speed of $2 \mathrm{~m} \mathrm{~s}^{-1}$. The weaker circulation is due to the combination of Coriolis acceleration and surface friction acting to create a region of convergence at the surface. Like the corkscrew sea breeze, the thickness of the onshore flow does not deviate substantially for increasing shore parallel gradient wind speed (Fig. 16).

Both the corkscrew and the backdoor sea breezes, produce stronger vector wind speeds offshore than at the coast unlike the pure sea breeze simulations (e.g. Fig. 17). Whilst the results are for $10 \mathrm{~m}$ wind speeds, the differences in wind

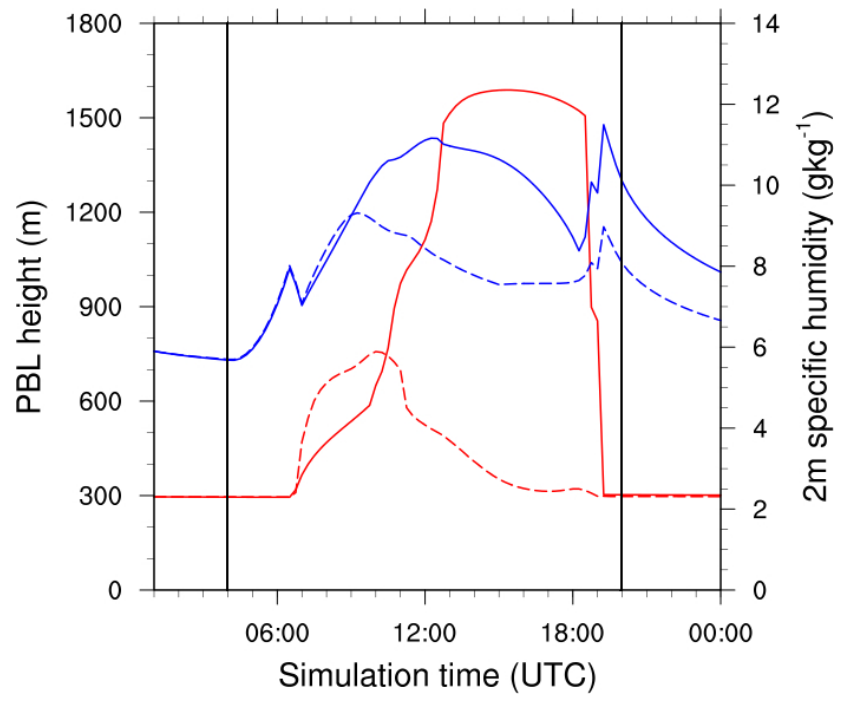

Fig. 13. 2 m specific humidity (blue) and PBL height (red) for a single coast corkscrew simulation with $2 \mathrm{~m} \mathrm{~s}^{-1}$ along-shore gradient winds. Solid and dashed lines represent values at $150 \mathrm{~km}$ onshore and at the coast, respectively. Sunrise and sunset are marked by the vertical black lines. The YSU PBL scheme was used in conjunction with a SST of $287 \mathrm{~K}$.

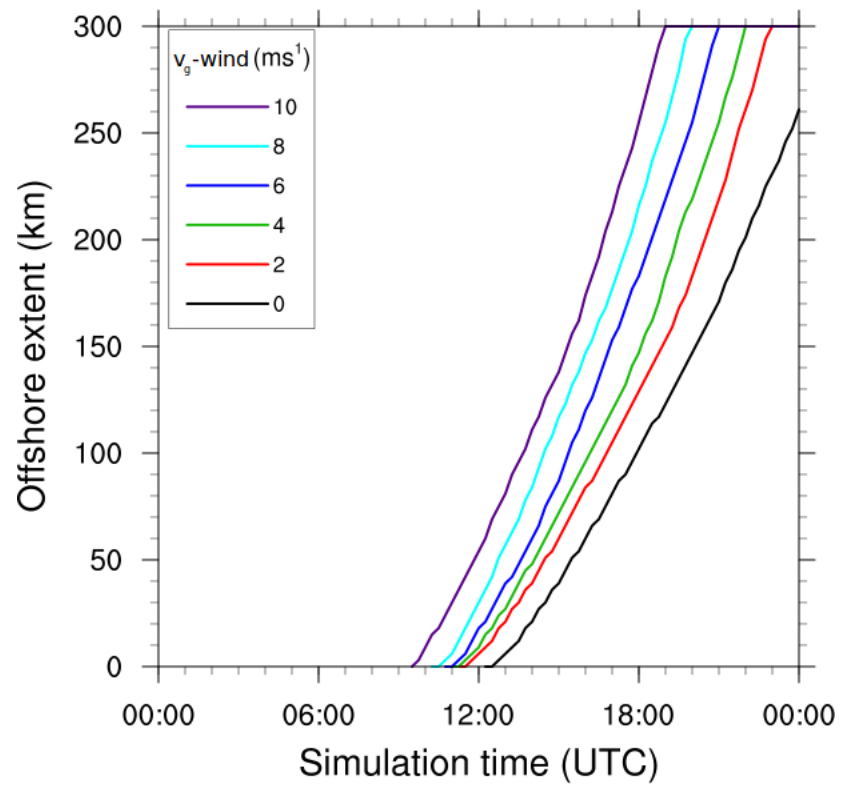

Fig. 14. Sensitivity of the onset time and of the offshore extent of single coast corkscrew sea breezes to the strength of the shoreparallel gradient flow. In all simulations, the YSU PBL scheme and a SST of $287 \mathrm{~K}$ were used.

speed offshore between different sea breeze types has potential implications for offshore wind energy. Significant deviations from predicted wind speeds are costly to the wind energy sector and so knowing the different effects of the sea breeze types is important. 


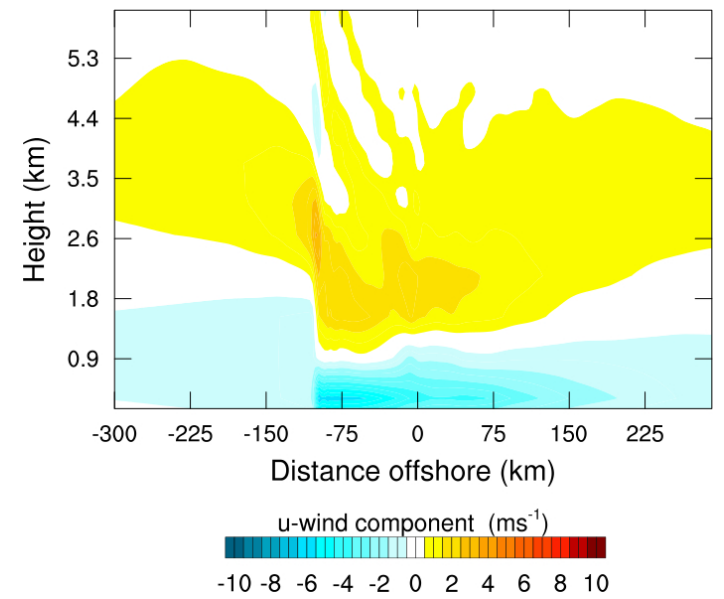

Fig. 15. Cross-section of a mature corkscrew sea breeze at 19:00 UTC developing in $2 \mathrm{~m} \mathrm{~s}^{-1}$ along shore gradient flow for the single coast case. The PBL used was the YSU scheme and the SST was $287 \mathrm{~K}$. The u-wind component is positive in the offshore direction.

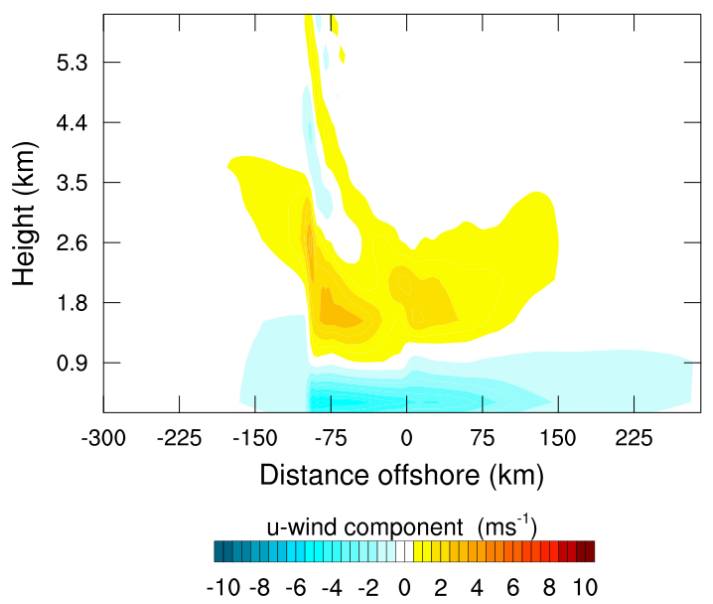

Fig. 16. Cross-section of a backdoor type sea breeze at 19:00 UTC generated with shore-parallel gradient winds of $-2 \mathrm{~m} \mathrm{~s}^{-1}$ for the single coast case. The YSU PBL scheme was used in conjunction with a SST of $287 \mathrm{~K}$.

\subsubsection{Sensitivity to thermodynamic profile}

In order to test the extent to which the results of the simulations were dependant on the initial thermodynamic profile, two further profiles were used for model initialization. Both profiles were from the same period of early June 2006 as the original but contrasted in terms of both stability and moisture availability (Fig. 5). Profile 2 is from 00:00 UTC at Herstmonceux on 2 June 2006 when the dominance of the anticyclone first established. The profile is saturated, or close to saturation, to $750 \mathrm{hPa}$ with a weak temperature inversion and relatively dry air above. This is indicative of low level cloud during nocturnal cooling of the PBL. A drier layer exists between $750-700 \mathrm{hPa}$, with another cloud layer to $500 \mathrm{hPa}$.
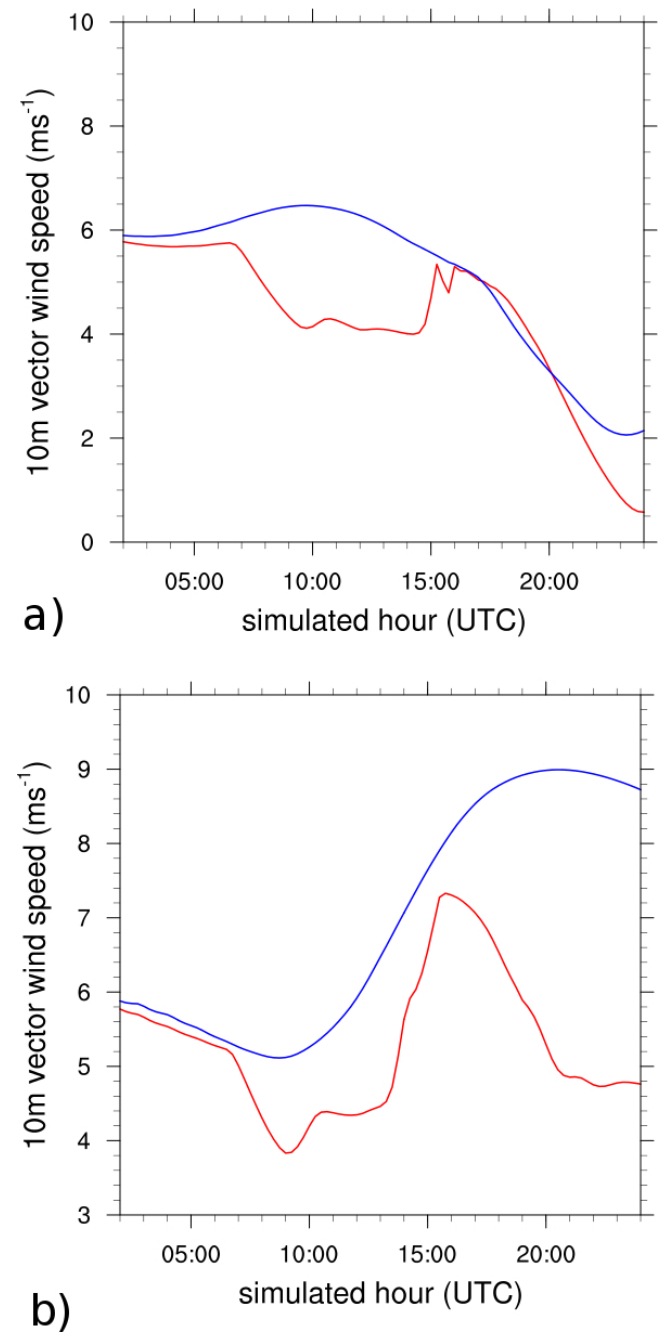

Fig. 17. The evolution of $10 \mathrm{~m}$ vector wind speed for backdoor (a) and corkscrew (b) sea breezes at the coast (red) and $30 \mathrm{~km}$ offshore (blue) in the single coast case. Shore-parallel gradient winds for both cases are of magnitude $6 \mathrm{~m} \mathrm{~s}^{-1}$. The YSU PBL scheme was selected for both cases along with a SST of $287 \mathrm{~K}$.

The second cloud layer is indicative of the remnants of a decaying frontal system to the north. This feature quickly decays and moves to the east and a sea breeze forms. For further details on the synoptic conditions please see the Supplement (Fig. S1). Profile 3 was observed at Herstmonceux at 00:00 UTC on 3 June 2006 and contains a much sharper temperature inversion at $860 \mathrm{hPa}$ and dryer air aloft.

The results of these baseline simulations show that only profile 2 produced any significant deviations offshore (Fig. 18) relative to those associated with the original profile shown in Fig. 4. Profile 2 formed a sea breeze with onshore winds of approximately $5 \mathrm{~m} \mathrm{~s}^{-1}$ and was the only single coast baseline experiment to extend to the edge of the $300 \mathrm{~km}$ offshore domain (Fig. S12a). In contrast, profile 3 forms a sea breeze which is weaker and only extends 


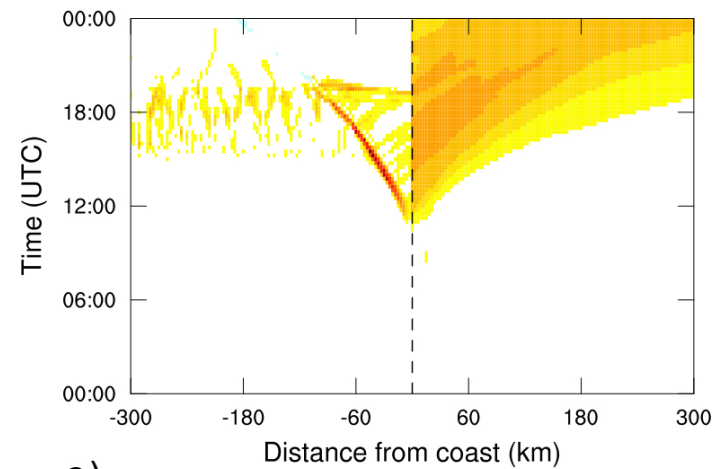

a)

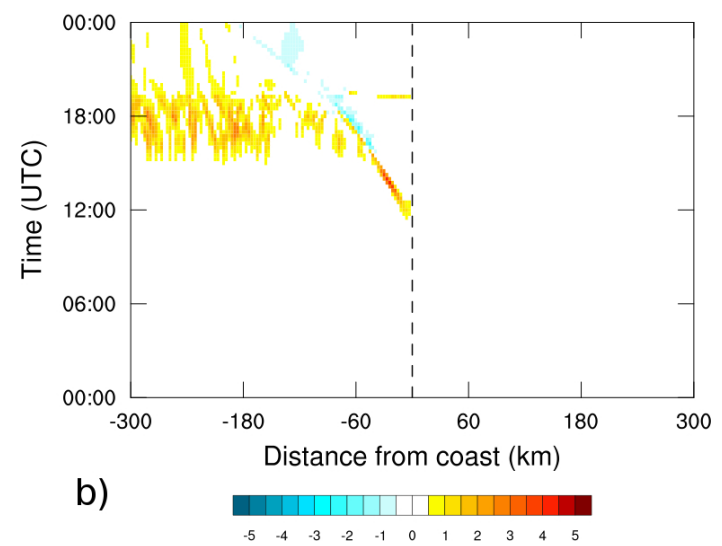

Fig. 18. Differences in u-wind speed between two single coast simulations using alternative initial profiles. Results based on 00:00 UTC profiles for 4 June 2006 (Fig. 4) subtracted from the results for (a) 3 and (b) 2 June 2006. In all cases, the YSU PBL and an SST of $287 \mathrm{~K}$ were used.

$222 \mathrm{~km}$ offshore, compared to profile 1 which extended $261 \mathrm{~km}$ offshore (Fig. S12b). The presence of the initial cloud cover in profile $2 \mathrm{kept}$ temperatures over land higher overnight, thereby intensified the land-sea air temperature contrast which subsequently developed during the daytime and consequently intensified the sea breeze. Other differences occurred over land and concerned the varying strength of the sea breeze front and the degree of convection ahead of the sea breeze. These differences are associated with any thermodynamic instabilities in the profiles.

In contrast to the baseline simulations, the pure, corkscrew and backdoor sea breeze simulations offshore all simulate a wide range of differences in wind velocities when compared to the simulations initialized with profile 1 (Figs. S13-S14). The strong inversion in profile 3 intensifies the region of divergence at the coast at approximately 06:15 UTC, when the land-sea thermal air temperature difference was zero. Overall offshore, the differing profiles produce only minor differences once the sea breeze had formed, unless the initial thermodynamic profile is close to saturation at night where the land-sea thermal contrast is intensified and the sea breeze is strengthened.

\subsubsection{Summary of single coast experiments}

In summary, there are notable differences between the types of sea breeze which warrant consideration. Corkscrew sea breezes are stronger circulations than pure types and can be produced under gradient wind speeds which are too high for a pure type to establish (Table 3 ). They also potentially have a much larger offshore extent and increase the wind speed offshore, unlike the pure type which acts to reduce the wind speed offshore. Backdoor sea breezes establish earlier than pure, however, surface convergence restricts the horizontal extent and strength of the backdoor. Potentially, the offshore extents of the different sea breeze types and related calm zones could therefore affect offshore wind farms in the southern North Sea. However the coastline of mainland Europe could modulate this and so we now move on to investigate the effect of an additional coastline in dual-coast simulations.

\subsection{Dual-coast}

\subsubsection{Baseline cases (no gradient wind)}

Similar to the previous single coastline example, a single simulation with no gradient winds superimposed was run this time for each boundary layer scheme. The simulation for the YSU scheme produced two symmetrical sea breezes on each coastline each with a peak offshore extent of $42 \mathrm{~km}$ at 17:00 UTC (Fig. 19). After this, the sea breeze retreats towards the coast until 19:00 UTC when no sea breeze was present offshore. The maximum strength of the onshore flow occurrs approximately $30 \mathrm{~km}$ inland at 15:00 UTC with a speed of $4 \mathrm{~m} \mathrm{~s}^{-1}$. Eventually the onshore extent reaches $60 \mathrm{~km}$, when the sea breeze subsides after 17:00 UTC. Onshore flow inland remained present although it was not continuous from the coast after this time. The PBL height and $2 \mathrm{~m}$ specific humidity simulated were comparable to the single coast simulation, reaching maxima of $1550 \mathrm{~m}$ and $13.5 \mathrm{~g} \mathrm{~kg}^{-1}$ respectively, $150 \mathrm{~km}$ onshore from the western coast (Fig. S15).

Both the MYJ and MYNN PBL schemes produce different baseline states (Fig. 19b and c). At 18:00 UTC both cases form convection ahead of the sea breeze. Furthermore, the MYJ scheme produces a much deeper PBL than the YSU baseline simulation, reaching $2300 \mathrm{~m}$, and with $2 \mathrm{~m}$ specific humidity of $21 \mathrm{~g} \mathrm{~kg}^{-1}$ at 13:00 UTC, $150 \mathrm{~km}$ onshore. The MYNN scheme forms a shallower PBL than the YSU, reaching a maximum depth of $1300 \mathrm{~m}$, however, it also simulated the highest $2 \mathrm{~m}$ specific humidities of $23 \mathrm{~g} \mathrm{~kg}^{-1}$ (Fig. S15).

\subsubsection{Pure sea breeze}

Without the inclusion of Coriolis forcing in the simulation, increasing the strength of the offshore gradient wind results in the western sea breeze retreating towards the sea. Indeed, for the YSU PBL scheme, the sea breeze does not reach the coastline at gradient wind speeds between $11-14 \mathrm{~m} \mathrm{~s}^{-1}$ 


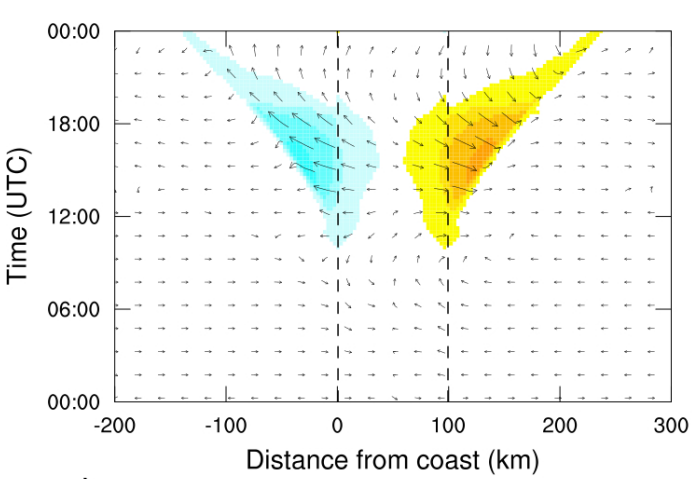

a)

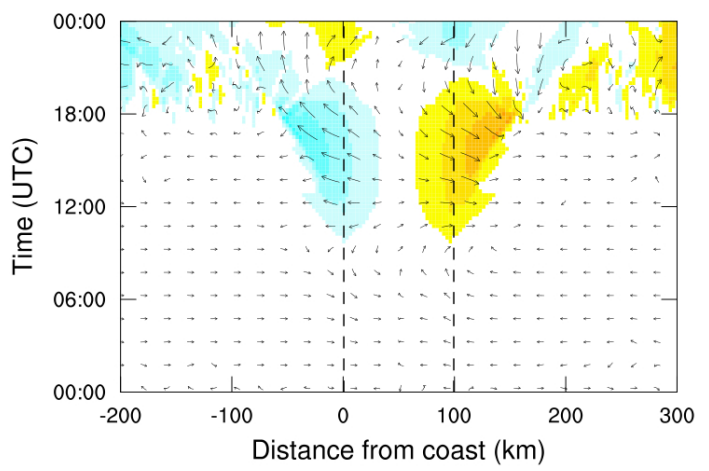

b)

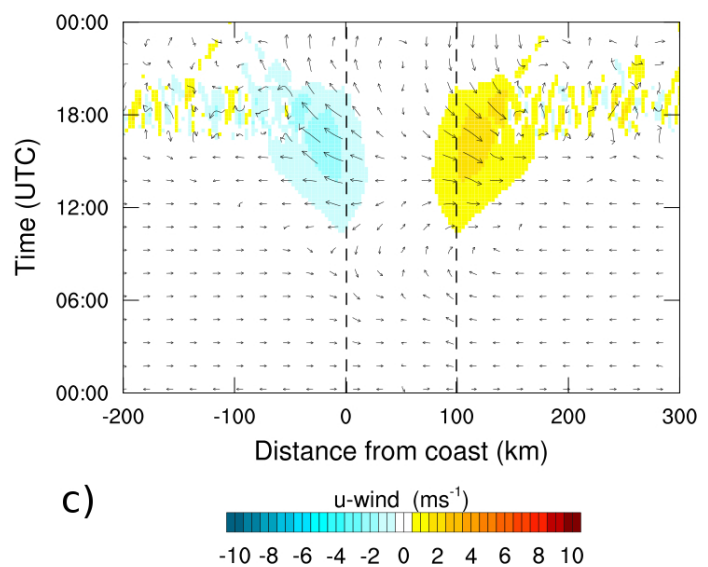

Fig. 19. Baseline windfield cases (no gradient wind) for dual-coast simulations using (a) YSU, (b) MYJ and (c) MYNN boundary layer schemes. Dashed lines represent each coastal boundary and distances are expressed as seaward from the western coastline. The SST for all simulations was $287 \mathrm{~K}$.

(Fig. 20). The offshore extent of the sea breeze was insensitive to gradient wind speed below $11 \mathrm{~m} \mathrm{~s}^{-1}$, reaching $42 \mathrm{~km}$ offshore.

With increasing gradient wind speed, both the MYJ and MYNN PBL schemes produce weaker onshore wind speeds in the offshore environment than the YSU scheme without the inclusion of Coriolis acceleration (Fig. 20). As a result, the maximum offshore gradient wind speed that forms a pure sea breeze circulation is $13 \mathrm{~m} \mathrm{~s}^{-1}$ for the YSU PBL scheme, compared to $10 \mathrm{~m} \mathrm{~s}^{-1}$ and $7 \mathrm{~m} \mathrm{~s}^{-1}$ for the MYJ and MYNN PBL scheme simulations, respectively. This is also a higher threshold than the previous single coast experiments using the YSU scheme. The confined sea in the dual-coast simulations is of insufficient length for the offshore gradient winds to fully adjust to the change in roughness length at the coast and is therefore more turbulent than with the single coast case. This means that the effective offshore gradient wind speed will be less than the single coast simulations and so the sea breeze will be able to form at higher gradient wind speeds for the dual-coast case.

The combination of the offshore calm zone $(10 \mathrm{~m}$ wind speed $<1 \mathrm{~m} \mathrm{~s}^{-1}$ ) and the offshore extent of the sea breeze extends to a greater distance with the YSU PBL, reaching $90 \mathrm{~km}$ offshore from the western coast compared with maxima of $72 \mathrm{~km}$ for both the MYJ and MYNN schemes without Coriolis acceleration. The pure sea breeze offshore extent of the PBL schemes are comparable, extending to $30 \mathrm{~km}$, though the sensitivity of the MYNN PBL scheme is greater to increasing gradient wind speed.

The inclusion of Coriolis acceleration reduces the minimum offshore gradient wind required to prevent the pure sea breeze from reaching the western coast (Table 4 and Fig. S16). Sensitivity of the minimum offshore gradient wind speed to PBL scheme is also apparent (Table 4). These range from $5 \mathrm{~m} \mathrm{~s}^{-1}$ with the MYNN PBL scheme to a maximum of $9 \mathrm{~m} \mathrm{~s}^{-1}$ using the YSU PBL scheme, and are consistent with the relative strengths of the sea breezes produced by each PBL scheme.

The inclusion of Coriolis acceleration also increases the sensitivity of the offshore extent of the pure sea breeze to increasing gradient wind speed (Fig. 21). The MYNN PBL scheme, in particular, does not simulate an onshore flow over the sea once Coriolis acceleration is included. With the YSU and MYJ schemes, the offshore extent does not become negligible until gradient wind speeds are above $7 \mathrm{~m} \mathrm{~s}^{-1}$ (Fig. S17).

Similarly, the offshore calm zone is more sensitive to increasing gradient wind speed with the inclusion of Coriolis acceleration although this is not the case for the YSU PBL experiments (Fig. S18). The calm zones for the YSU simulations vary in length between approximately $50-70 \mathrm{~km}$ and are still generated with an offshore gradient wind speed of $10 \mathrm{~m} \mathrm{~s}^{-1}$; when the sea breeze is not formed (Fig. S18). The MYJ and MYNN PBL simulations do not produce a calm zone for offshore gradient wind speeds above $6 \mathrm{~m} \mathrm{~s}^{-1}$ (Fig. S18).

In summary, the behaviour of the pure sea breeze offshore is strongly influenced by the choice of PBL scheme (Table 4). The two TKE schemes tested simulate a pure sea breeze that is shorter, weaker and more sensitive to gradient wind speed changes than the non-local YSU scheme. The MYNN PBL scheme in particular does not simulate a sea breeze in the offshore environment that meets the definition given by Arritt (1989). 
Table 4. Summary of pure sea breeze dual-coast characteristics for varying offshore gradient wind speeds and PBL schemes. The detachment wind speed is the minimum offshore gradient wind speed required to prevent a sea breeze from reaching the coast. The maximum offshore extent is defined as the maximum continuous distance offshore that the $\mathrm{u}$-wind component is less than $-1 \mathrm{~m} \mathrm{~s}^{-1}$. The calm zone length is defined as a continuous region with wind speed below $1 \mathrm{~m} \mathrm{~s}^{-1}$. The flow retardation percentage is the percentage drop in $10 \mathrm{~m}$ wind speed over the water surface due to the thermal contrast relative to the average value at 03:00 UTC. Supporting figures can be found in the Supplement (Figs. S15-S17).

\begin{tabular}{|c|c|c|c|c|c|c|c|c|c|}
\hline \multirow{3}{*}{$\begin{array}{l}\text { Parameter } \\
\text { PBL scheme } \\
\text { Gradient wspd }\left(\mathrm{m} \mathrm{s}^{-1}\right)\end{array}$} & \multicolumn{9}{|c|}{ Pure } \\
\hline & \multicolumn{3}{|c|}{ YSU } & \multicolumn{3}{|c|}{ MYJ } & \multicolumn{3}{|c|}{ MYNN } \\
\hline & 3 & 9 & 15 & 3 & 9 & 15 & 3 & 9 & 15 \\
\hline detachment wspd $\left(\mathrm{m} \mathrm{s}^{-1}\right)$ & & 9 & & & 8 & & & 5 & \\
\hline Max. offshore extent (km) & & 18 & & & 15 & & & 0 & \\
\hline Calm zone length (km) & 66 & 48 & 0 & 48 & 0 & 0 & 66 & 0 & 0 \\
\hline Flow retardation $(\%)$ & 75 & 75 & 79 & 60 & 66 & - & 75 & 75 & 65 \\
\hline Max. onshore wspd $\left(\mathrm{m} \mathrm{s}^{-1}\right)$ & 3.14 & 0.93 & - & 2.95 & 0.26 & - & 1.73 & - & - \\
\hline
\end{tabular}

Conversely, the inclusion of the second coastline allows the formation of a sea breeze in higher gradient wind speeds than the single coast simulations, though the length of both the offshore extent of the sea breeze and the calm zones are restricted by the inclusion of the second coastline. In context, though these are only idealized experiments, both the offshore calm zones and the pure sea breeze would influence any offshore wind farms, bringing the wind resource below the cut in threshold required to operate a turbine.

\subsubsection{Corkscrew and backdoor cases}

For a shore-parallel gradient wind without Coriolis acceleration, two symmetrical corkscrew and backdoor sea breezes are formed on each coastline for all gradient wind speeds (Fig. S19). The inclusion of Coriolis acceleration however produces the asymmetry which allows the two sea breeze types to be distinguishable from each other (Fig. 22).

For all PBL schemes, increasing the strength of the alongshore gradient wind speed increases the extent and strength of the corkscrew sea breeze both onshore and offshore on the western coast, as per the single coast results (Table 5 and Fig. 22). This implies that the enhancement of the corkscrew sea breeze by creation of the region of divergence at the coast becomes increasingly important with increasing gradient wind speed. The least sensitive PBL schemes to gradient wind speed changes are the YSU and MYJ schemes (Fig. 22b and c). As with the pure case, the MYNN scheme produces an offshore extent which is the smallest, reaching only $12 \mathrm{~km}$ for shore-parallel gradient wind speeds between $1-8 \mathrm{~m} \mathrm{~s}^{-1}$. Above this speed, the corkscrew sea breeze offshore extension rapidly increases so that by 17:00 UTC, a gradient wind speed of $9 \mathrm{~m} \mathrm{~s}^{-1}$ is sufficient for the sea breeze to reach $96 \mathrm{~km}$ offshore (Fig. 20c and Table 6).

In contrast to the corkscrew, the backdoor sea breeze on the eastern coast has both the largest horizontal extent and strength at the lowest gradient wind speeds for all PBL schemes. There is little fluctuation in offshore extent until the point where the corkscrew sea breeze on the western coast prevents the formation of the backdoor sea breeze on the eastern. This varies for each PBL scheme. For the YSU scheme both the maximum offshore extent and the strength of the gradient wind speed required to prevent sea breeze formation are the maximum between the different PBL schemes with values of $30 \mathrm{~km}$ and $15 \mathrm{~m} \mathrm{~s}^{-1}$, respectively (Fig. 22a).

Both the corkscrew and backdoor sea breezes do not suffer the degree of flow retardation as the pure sea breeze does by the formation of calm zones (compare Tables 4, 5 and 6). In some of the corkscrew sea breeze experiments, the sea breeze enhances the gradient wind speed as shown by the negative values in Table 5.

In summary, the factor responsible for the development of the asymmetries which distinguish the sea breeze types in shore parallel flow is Coriolis acceleration when interacting with surface friction. For the corkscrew case, the creation of the region of divergence by Coriolis acceleration becomes increasingly important with increasing gradient wind speed to the degree that the corkscrew sea breeze restricts the development of the backdoor sea breeze on the eastern coastline. Also, for the wind speeds tested, increasing the strength of the along-shore gradient wind does not prevent the formation of a backdoor sea breeze, so this type is not restricted to low wind speeds, unlike the more intensely studied pure type.

\subsubsection{SST variations}

With the exception of the sea breeze front, varying the SST between 280-290 K (a realistic SST range in southern North Sea temperatures for June) does not have a significant effect on the onshore environment for any type of sea breeze (Figs. 23 and S20-S23). Offshore, however, the result of increasing the sea surface skin temperature is to reduce the land-sea thermal contrast and therefore to weaken the sea 


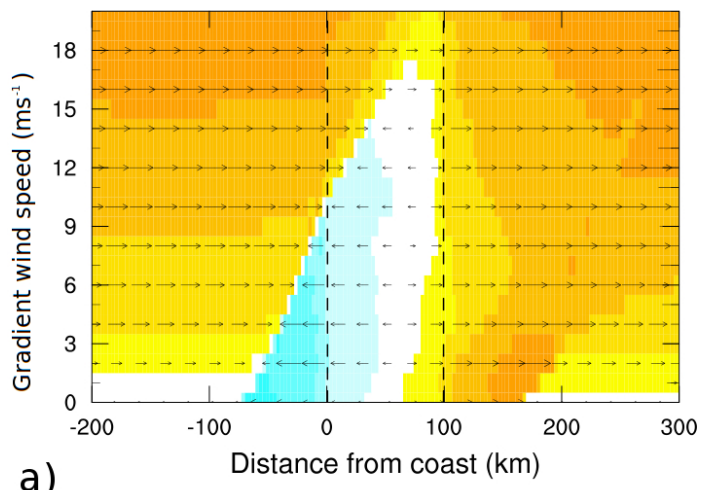

a)
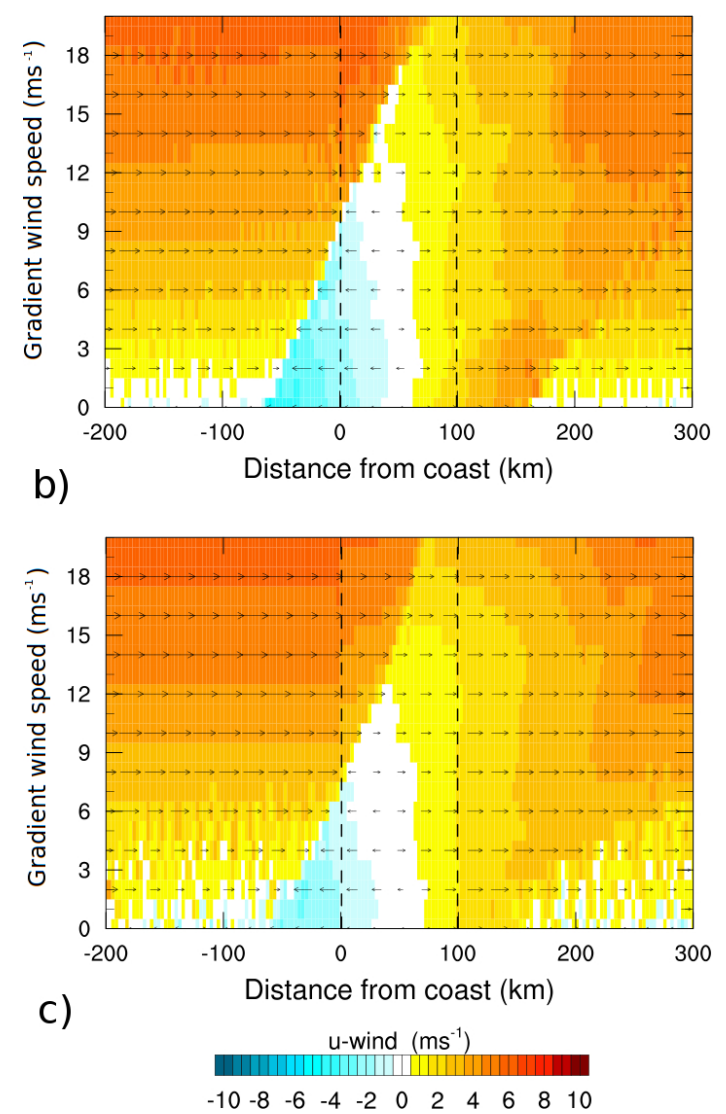

Fig. 20. Variations of the $10 \mathrm{~m} \mathrm{u}$-wind component (color) and vector wind speeds (arrows) with increasing west-east gradient wind strength at 17:00 UTC using the (a) YSU, (b) MYJ and (c) MYNN PBL schemes without Coriolis acceleration. Distances are measured from the western coastal boundary with each coastline being depicted by the dashed lines. In all cases, the SST was $287 \mathrm{~K}$.

breeze. In other words, the calm zone diminishes and the offshore wind speeds increase. For example, the magnitude of the increase in wind speed for sea surface skin temperatures between $280 \mathrm{~K}$ and $290 \mathrm{~K}$ is $1-2 \mathrm{~m} \mathrm{~s}^{-1}$ for offshore gradient wind speeds below $4 \mathrm{~m} \mathrm{~s}^{-1}$ (Fig. S23). At offshore gradient wind speeds above $4 \mathrm{~m} \mathrm{~s}^{-1}$, the change in offshore wind
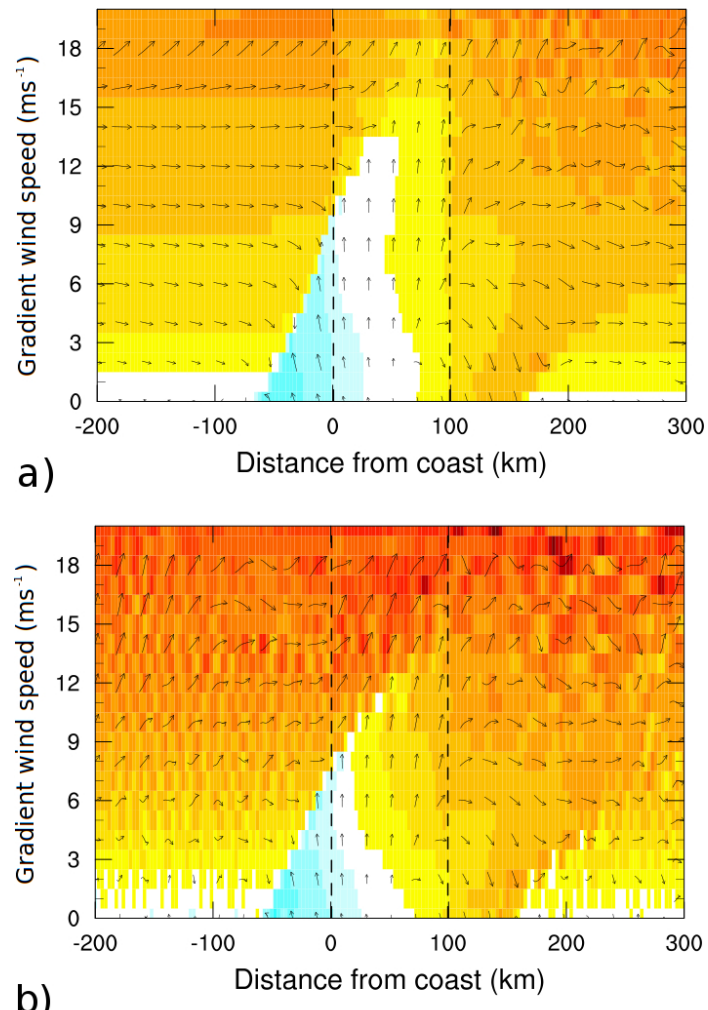

b)

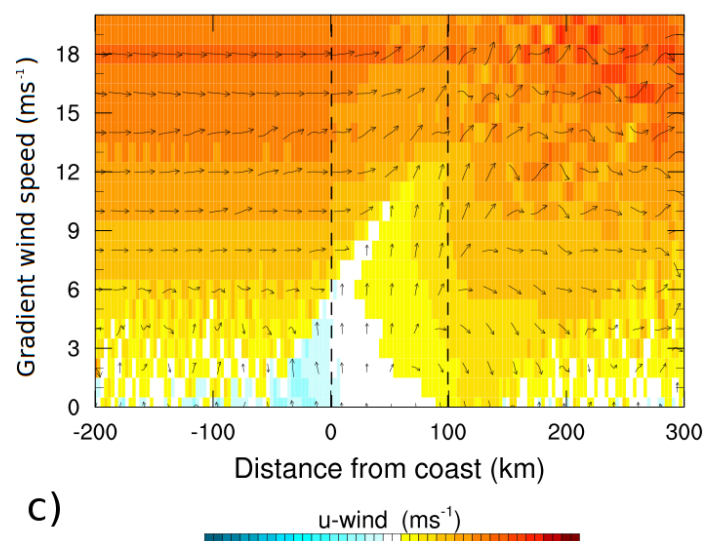

$\begin{array}{lllllllllll}-10 & -8 & -6 & -4 & -2 & 0 & 2 & 4 & 6 & 8 & 10\end{array}$

Fig. 21. Variations of the $10 \mathrm{~m} \mathrm{u}$-wind component (color) and vector wind speeds (arrows) with increasing west-east gradient wind strength at 17:00 UTC using the (a) YSU, (b) MYJ and (c) MYNN PBL schemes with Coriolis acceleration. Distances are measured from the western coastal boundary with each coastline being depicted by the dashed lines. The SST was set to $287 \mathrm{~K}$ for all simulations.

speed as a function of SST diminishes, as the gradient flow dominates the thermal pressure gradient.

For pure sea breeze circulations, the increase in SST decreases the minimum wind speed required to prevent the sea breeze circulation from reaching the land (Fig. S23; Table 7). Fundamentally, this is to be expected and indeed several sea breeze prediction methods rely on the ratio of gradient winds 
Table 5. Summary of corkscrew sea breeze dual-coast characteristics for varying offshore gradient wind speeds and PBL schemes. The maximum offshore extent is defined as the maximum continuous distance offshore that the $\mathrm{u}$-wind component is less than $-1 \mathrm{~m} \mathrm{~s}{ }^{-1}$. The calm zone length is defined as a continuous region with wind speed below $1 \mathrm{~m} \mathrm{~s}^{-1}$. The flow retardation percentage is the percentage drop in $10 \mathrm{~m}$ wind speed over the water surface due to the thermal contrast relative to the average value at 03:00 UTC. Negative values represent an increase in $10 \mathrm{~m}$ wind speed.

\begin{tabular}{|c|c|c|c|c|c|c|c|c|c|}
\hline \multirow{3}{*}{$\begin{array}{l}\text { Parameter } \\
\text { PBL scheme } \\
\text { Gradient wspd }\left(\mathrm{m} \mathrm{s}^{-1}\right)\end{array}$} & \multicolumn{9}{|c|}{ Corkscrew } \\
\hline & \multicolumn{3}{|c|}{ YSU } & \multicolumn{3}{|c|}{ MYJ } & \multicolumn{3}{|c|}{ MYNN } \\
\hline & 3 & 9 & 15 & 3 & 9 & 15 & 3 & 9 & 15 \\
\hline Max. offshore extent $(\mathrm{km})$ & \multicolumn{3}{|c|}{81} & \multicolumn{3}{|c|}{97} & \multicolumn{3}{|c|}{97} \\
\hline Flow retardation $(\%)$ & -71 & 0 & 12 & -70 & -27 & 0 & -57 & 9 & 22 \\
\hline Max. onshore wspd $\left(\mathrm{m} \mathrm{s}^{-1}\right)$ & 3.34 & 3.23 & 3.39 & 2.83 & 3.38 & 4.23 & 1.83 & 2.37 & 3.12 \\
\hline
\end{tabular}

Table 6. Summary of backdoor sea breeze dual-coast characteristics for varying offshore gradient wind speeds and PBL schemes. The maximum offshore extent is defined as the maximum continuous distance offshore that the $\mathrm{u}$-wind component is less than $-1 \mathrm{~m} \mathrm{~s}^{-1}$. The corkscrew dominance is defined as the wind speed where the offshore influence of the corkscrew sea breeze, formed on the opposing coastline, suppresses the backdoor sea breeze offshore. The calm zone length is defined as a continuous region with wind speed below $1 \mathrm{~m} \mathrm{~s}^{-1}$. The flow retardation percentage is the percentage drop in $10 \mathrm{~m}$ wind speed over the water surface due to the thermal contrast relative to the average value at 03:00 UTC.

\begin{tabular}{|c|c|c|c|c|c|c|c|c|c|}
\hline \multirow{3}{*}{$\begin{array}{l}\text { Parameter } \\
\text { PBL scheme } \\
\text { Gradient wspd }\left(\mathrm{m} \mathrm{s}^{-1}\right)\end{array}$} & \multicolumn{9}{|c|}{ Backdoor } \\
\hline & \multicolumn{3}{|c|}{ YSU } & \multicolumn{3}{|c|}{ MYJ } & \multicolumn{3}{|c|}{ MYNN } \\
\hline & 3 & 9 & 15 & 3 & 9 & 15 & 3 & 9 & 15 \\
\hline Cork. dominance $\left(\mathrm{m} \mathrm{s}^{-1}\right)$ & & 5 & & & 11 & & & 9 & \\
\hline Max. offshore extent (km) & & 24 & & & 27 & & & 24 & \\
\hline Flow retardation $(\%)$ & 29 & - & - & 36 & 10 & - & 43 & 22 & - \\
\hline Max. onshore wspd $\left(\mathrm{m} \mathrm{s}^{-1}\right)$ & 3.44 & 2.12 & 1.37 & 2.15 & 2.53 & 0.55 & 1.45 & 1.63 & 1.12 \\
\hline
\end{tabular}

Table 7. Dual-coast pure sea breeze response to varying SST. In both cases the YSU PBL scheme was selected and the simulations run with $2 \mathrm{~m} \mathrm{~s}^{-1}$ offshore gradient winds. Supporting figures can be found in the Supplement (Fig. S20-S21).

\begin{tabular}{|c|c|c|c|c|c|c|}
\hline \multirow{3}{*}{$\begin{array}{l}\text { Parameter } \\
\text { SST } \\
\text { Gradient wspd }\left(\mathrm{m} \mathrm{s}^{-1}\right)\end{array}$} & \multicolumn{6}{|c|}{ Pure sea breeze SST sensitivity } \\
\hline & \multicolumn{3}{|c|}{$280 \mathrm{~K}$} & \multicolumn{3}{|c|}{$290 \mathrm{~K}$} \\
\hline & 3 & 9 & 15 & 3 & 9 & 15 \\
\hline Detachment wspd $\left(\mathrm{m} \mathrm{s}^{-1}\right)$ & & 10 & & & 8 & \\
\hline Max. offshore extent (km) & & 15 & & & 33 & \\
\hline Calm zone length (km) & 66 & 45 & 0 & 57 & 18 & 0 \\
\hline Flow retardation $(\%)$ & 83 & 75 & - & 87 & 86 & 70 \\
\hline Max. onshore wspd $\left(\mathrm{m} \mathrm{s}^{-1}\right)$ & 3.08 & 1.68 & - & 2.97 & 0.89 & - \\
\hline
\end{tabular}

to land-sea thermal contrast (e.g. Biggs and Graves, 1962). Without the effect of advection cooling the land surface with increasing offshore gradient wind speed, the sea breeze horizontal length scales are insensitive to the SST's simulated (Figs. S20 and S21).

Additionally, a recent case study by Tang (2012) for an individual event has suggested that the effects of the diurnal cycle on shallow coastal water temperatures has significant impact on the sea breeze. To our knowledge, there has been no such idealized investigation into the effects of a shallow water diurnal cycle on the sea breeze. Adding such a cycle may reduce the land-sea thermal gradient and therefore lead to a weaker sea breeze.

\section{Summary and conclusions}

A series of idealized numerical experiments of different sea breeze types have been performed and the additional constraint of a second coastal boundary has been tested. Of 


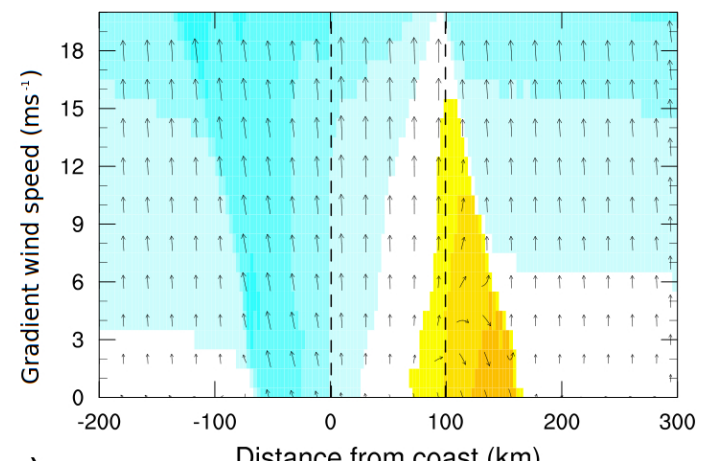

a)

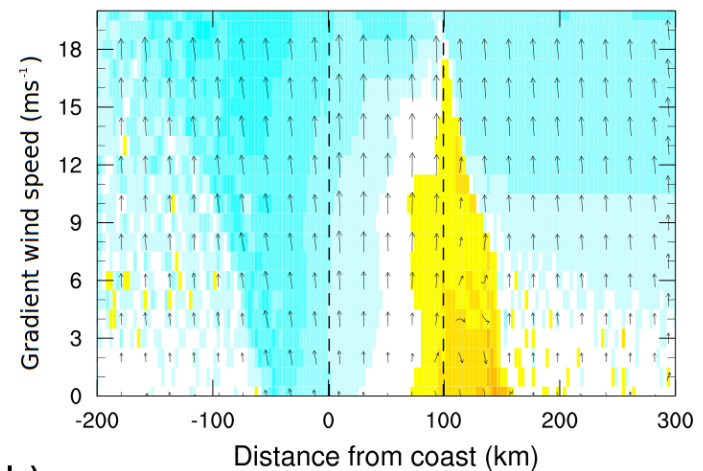

b)

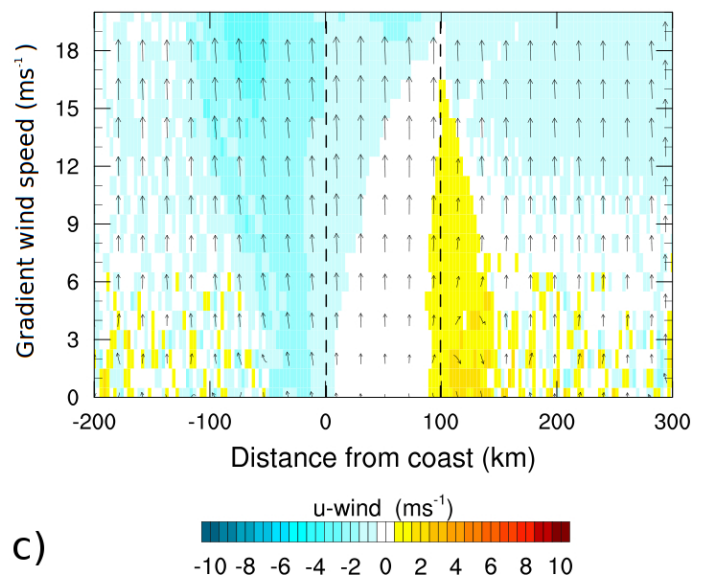

Fig. 22. Variations of $10 \mathrm{~m}$ u-wind component (colour) with $10 \mathrm{~m}$ wind vectors (arrows) for increasing south-north gradient winds at 17:00 UTC using the (a) YSU, (b) MYJ and (c) MYNN PBL schemes. Coriolis acceleration is enabled for a latitude of $52^{\circ}$ and distances are measured from the western coast. The SST was set at $287 \mathrm{~K}$ for all simulations.

particular interest are the sea breeze characteristics and impact offshore, as extensive offshore wind farm development is currently underway in, for example, the southern North Sea. Sensitivity tests have also been performed regarding PBL physics schemes, initial thermodynamic profile, coriolis effect and realistic variations in sea surface skin temperature.

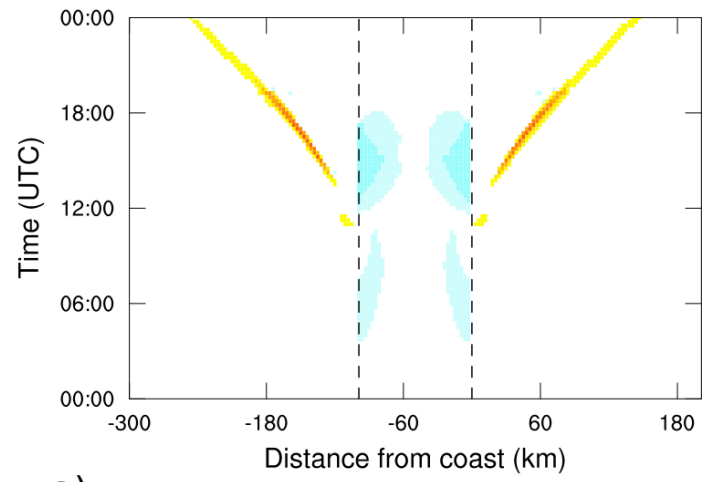

a)

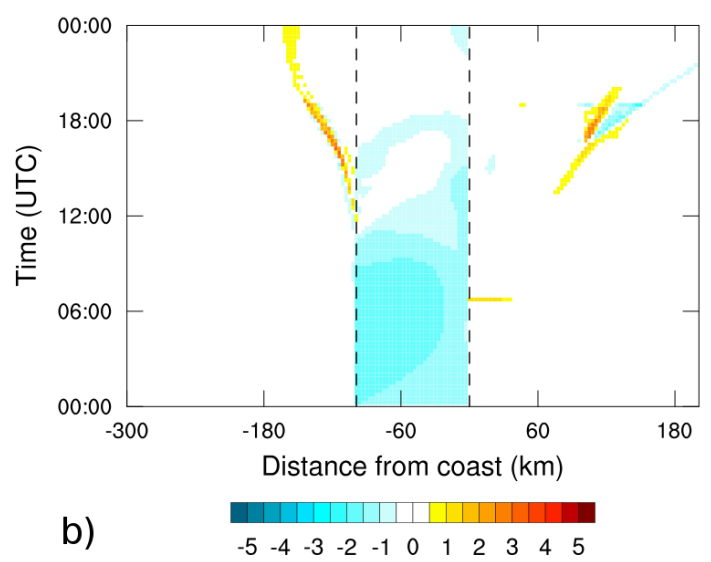

Fig. 23. Differences in $10 \mathrm{~m} \mathrm{u}$-wind component for (a) the baseline case and for (b) $4 \mathrm{~m} \mathrm{~s}^{-1}$. In each figure, the differences represent a simulation with sea surface skin temperature of $290 \mathrm{~K}$ subtracted from a $280 \mathrm{~K}$ simulation. In all cases, the YSU PBL was selected.

Principally, it is found that consideration must be given to the sea breeze type, if accurate prediction of the sea breeze characteristics is to be achieved. This is especially important offshore, as both corkscrew and backdoor types produce higher wind speeds here than at the coast. In contrast to this, the pure sea breeze causes a reduction in wind speed offshore relative to the coastline.

The inclusion of the second coastline, more realistically representing the southern North Sea, enhances the effect of the offshore calm zones $\left(<1 \mathrm{~m} \mathrm{~s}^{-1}\right)$ which frequently span a large proportion of the modelled water surface, but are prevented from advancing as far as the single coast cases by the inclusion of the second coastline. Also, the pure sea breeze is able to form in higher offshore gradient wind speeds than in the single coast case; the smaller water surface does not allow the airflow to fully adjust before arrival at the second coastal boundary and so the airflow here is more turbulent, reducing the effective wind speed. Both the presence of the second coastline and the sea breeze type considered potentially have significant implications for offshore wind farms. This result is not particularly sensitive to realistic SST variations for the baseline case, however, for the pure type sea breeze, 
the effective thermal contrast is reduced for increasing offshore gradient wind speed and so consequently, the threshold gradient wind speed required to prevent the sea breeze from reaching the coastline is reduced. There are also important differences with regard to the PBL scheme used. In particular, the MYNN scheme simulates much weaker pure sea breezes offshore, extending to less than $10 \mathrm{~km}$ for the majority of simulations, yet the extent of the simulated calm zone is comparable to other PBL schemes.

For all of the shore-parallel gradient wind simulations, a corkscrew sea breeze was formed on the western coast, and was intensified offshore relative to the baseline case (no gradient wind). Increasing the gradient wind speed further extended the corkscrew sea breeze offshore until it reached the opposite coastline. This occurred for all PBL schemes.

Since a corkscrew type sea breeze occurred on the opposite coastline to the backdoor sea breeze, the offshore extent of the backdoor sea breeze was restricted by the corkscrew. Consequently, the circulation was restricted to its own coastline. This, however, only occurred when Coriolis was enabled. Without Coriolis rotation, both coastlines produced identical sea breezes, and the distinct corkscrew and backdoor types were not generated. This implies that Coriolis acceleration plays an important role in forming the different sea breeze types, and that in particular, the divergence associated with the corkscrew sea breeze becomes increasingly important with increasing gradient wind speed.

Whilst these results are purely idealized, they present an indication to the forecaster of the sea breeze dependence on both prognostic variables and physical model settings. Further research will be carried out through the modelling of real events coupled to realistic coastlines and combined with verification of the results against measurements from offshore wind farms in the southern North Sea to help determine the relative performance of the respective PBL schemes.

\section{Supplementary material related to this article is available online at: http://www.atmos-chem-phys.net/13/ 443/2013/acp-13-443-2013-supplement.pdf.}

Acknowledgements. The authors would like to acknowledge both the Natural Environmental Research Council (NERC) and Weatherquest Ltd. for providing the funding to make this research possible.

Edited by: B. Vogel

\section{References}

Abbs, D. J. and Physick, W. L.: Sea-breeze observations and modelling: a review, Aust. Meteorol. Mag., 41, 7-19, 1992.

Arritt, R. W.: Numerical modelling of the offshore extent of sea breezes, Q. J. Roy. Meteorol. Soc., 115, 547-570, 1989.
Azorin-Molina, C. and Chen, D.: A climatological study of the influence of synoptic-scale flows on sea breeze evolution in the Bay of Alicante (Spain), Theor. Appl. Climatol., 96, 249-260, doi:10.1007/s00704-008-0028-2, 2009.

Azorin-Molina, C., Chen, D., Tijm, S., and Baldi, M.: A multi-year study of sea breezes in a Mediterranean coastal site: Alicante (Spain), Int. J. Climatol., 31, 468-486, 2011a.

Azorin-Molina, C., Tijm, S., and Chen, D.: Development of selection algorithms and databases for sea breeze studies, Theor. Appl. Climatol., 106, 531-546, doi:10.1007/s00704-011-04544, $2011 b$.

Bianco, L., Tomassetti, B., Coppola, E., Fracassi, A., Verdecchia, M., and Visconti, G.: Thermally driven circulation in a region of complex topography: comparison of wind-profiling radar measurements and MM5 numerical predictions, Ann. Geophys., 24, 1537-1549, doi:10.5194/angeo-24-1537-2006, 2006.

Biggs, W. G. and Graves, M. E.: A lake breeze index, J. Appl. Meteorol., 1, 474-480, 1962.

Borge, R., Alexandrov, V., José del Vas, J., Lumbreras, J., and Rodríguez, E.: A comprehensive sensitivity analysis of the WRF model for air quality applications over the Iberian Peninsula, Atmos. Environ., 42, 8560-8574, doi:10.1016/j.atmosenv.2008.08.032, 2008.

Golding, B., Clark, P., and May, B.: The Boscastle flood: Meteorological analysis of the conditions leading to flooding on $16 \mathrm{Au}-$ gust 2004, Weather, 60, 230-235, doi:10.1256/wea.71.05, 2005.

Challa, V. S., Indracanti, J., Rabarison, M. K., Patrick, C., Baham, J. M., Young, J., Hughes, R., Hardy, M. G., Swanier, S. J., and Yerramilli, A.: A simulation study of mesoscale coastal circulations in Mississippi Gulf coast, Atmos. Res., 91, 9-25, doi:10.1016/j.atmosres.2008.05.004, 2009.

Clarke, R. H.: Sea-breezes and waves: the "Kalgoorlie sea-breeze" and the "Goondiwindi breeze", Aust. Meteorol. Mag., 37, 99107, http://www.bom.gov.au/amm/papers.php?year=1989, 1989.

Clarke, R. H., Smith, R. K., and Reid, D. G.: The morning glory of the Gulf of Carpentaria: an atmospheric undular bore, Monthly Weather Review, 109, 1726-1750, http://journals.ametsoc.org/doi/abs/10.1175/1520-0493(1981) 109\%3C1726:TMGOTG\%3E2.0.CO\%3B2, 1981.

Cleantech: Jefferies CleanTech Review, http://energy.wesrch.com, 2010.

Crosman, E. T. and Horel, J. D.: Sea and Lake Breezes: A review of Numerical Studies, Bound.-Lay. Meteorol., 137, 1-29, doi:10.1007/s10546-010-9517-9, 2010.

Crosman, E. and Horel, J.: Idealized Large-Eddy Simulations of Sea and Lake Breezes: Sensitivity to Lake Diameter, Heat Flux and Stability, Bound.-Lay. Meteorol., 144, 309-328, doi:10.1007/s10546-012-9721-x, 2012.

Earl, N., Dorling, S., Hewston, R., and von Glasow, R.: 19802010 variability in UK surface wind climate, J. Climate, doi:10.1175/JCLI-D-12-00026.1, in press, 2012.

Esau, I. and Byrkjedal, Ø.: Application of a Large-Eddy Simulation Database to Optimisation of First-Order Closures for Neutral and Stably Stratified Boundary Layers, Bound.-Lay. Meteorol., 125, 207-225, doi:10.1007/s10546-007-9213-6, 2007.

Fernández-Camacho, R., Rodríguez, S., de la Rosa, J., Sánchez de la Campa, A. M., Viana, M., Alastuey, A., and Querol, X.: Ultrafine particle formation in the inland sea breeze airflow in Southwest Europe, Atmos. Chem. Phys., 10, 9615-9630, doi:10.5194/acp- 
10-9615-2010, 2010.

Finkele, K.: Inland and offshore propagation speeds of a sea breeze from simulations and measurements, Bound.-Lay. Meteorol., 87, 307-329, 1998.

Furberg, M., Steyn, D. G., and Baldi, M.: The climatology of sea breezes on Sardinia, Int. J. Climatol., 22, 917-932, doi:10.1002/joc.780, 2002.

Gahmberg, M., Savijarvi, H., and Leskimen, M.: The influence of synoptic scale flow on sea breeze induced surface winds and calm zones, Tellus, 62A, 209-217, 2010.

Hoddinott, M. H. O.: Failure of the sea-breeze in Chester during a hot spell, Weather, 64, p. 310, doi:10.1002/wea.491, 2009.

Hong, S. Y., Noh, Y., and Dudhia, J.: A new vertical diffusion package with an explicit treatment of entrainment processes, Mon. Weather Rev., 134, 2318-2341, 2006.

Klemp, J. B. and Lilly, D. K.: Numerical Simulation of Hydrostatic Mountain Waves, J. Atmos. Sci., 35, 78-107, doi:10.1175/15200469(1978)035<0078:NSOHMW>2.0.CO;2, 1978.

Krogsaeter, O., Reuder, J., and Hauge, G.: WRF and the marine planetary boundary layer, http://www.mmm.ucar.edu/wrf/users/ workshops/WS2011/WorkshopPapers.php, 12th Annual WRF users' workshop, 2011.

Lapworth, A.: The diurnal variation of the marine surface wind in an offshore flow, Q. J. Roy. Meteor. Soc., 131, 2367-2387, doi:10.1256/qj.04.161, 2005.

Lee, S.-H., Kim, S.-W., Angevine, W. M., Bianco, L., McKeen, S. A., Senff, C. J., Trainer, M., Tucker, S. C., and Zamora, R. J.: Evaluation of urban surface parameterizations in the WRF model using measurements during the Texas Air Quality Study 2006 field campaign, Atmos. Chem. Phys., 11, 2127-2143, doi:10.5194/acp-11-2127-2011, 2011.

Mellor, G. L. and Yamada, T.: Development of a turbulence closure model for geophysical fluid problems, Rev. Geophys. Space Phys., 20, 851-875, 1982.

Miller, S. T. K., Keim, B. D., Talbot, R. W., and Mao, H.: Sea Breeze: Structure, Forecasting and Impacts, Rev. Geophys., 41, 1011-1042, 2003.
Papanastasiou, D., Melas, D., and Lissaridis, I.: Study of wind field under sea breeze conditions; an application of WRF model, Atmos. Res., 98, 102-117, doi:10.1016/j.atmosres.2010.06.005, 2010.

Qian, T., Epifanio, C. C., and Zhang, F.: Linear theory calculations for the sea breeze in a background wind: The equatorial case, J. Atmos. Sci., 66, 1749-1763, 2009.

RenewableUK: http://www.bwea.com/offshore/index.html, 2012.

Savijarvi, H. and Alestalo, M.: The Sea Breeze over a lake or Gulf as the function of the prevailing flow, Beitr. Phys. Atmosph., 61, 98-104, 1988.

Simpson, J. E.: Sea breeze and local winds, Cambridge University Press, 1994.

Simpson, J. E., Mansfield, D. A., and Milford, J. R.: Inland penetration of sea-breeze fronts, Q. J. Roy. Meteor. Soc., 103, 47-76, doi:10.1002/qj.49710343504, 1977.

Sinden, G.: Wind power and the UK wind resource, Tech. rep., Environmental Change Institute, University of Oxford, 2005.

Skamarock, W. C. and Klemp, J. B.: A time-split nonhydrostatic atmospheric model for weather research and forecasting applications, J. Comput. Phys., 227, 3465-3485, doi:10.1016/j.jcp.2007.01.037, 2008.

Sun, W.-Y. and Ogura, Y.: Modeling the Evolution of the Convective Planetary Boundary Layer, J. Atmos. Sci., 37, 1558-1572, 1980.

Tang, Y.: The Effect of Variable Sea Surface Temperature on Forecasting Sea Fog and Sea Breezes: A Case Study, J. Appl. Meteorol. Clim., 51, 986-990, doi:10.1175/JAMC-D-11-0253.1, 2012.

Tsunematsu, N., Iwai, H., Murayama, Y., Yasui, M., and Mizutani, K.: The formation of sharp multi-layered wind structure over Tokyo associated with sea-breeze circulation, Scientific Online Letters on the Atmosphere, 5, 1-4, https://www.jstage.jst.go.jp/ article/sola/5/0/5_0_1/_article, 2009. 